\title{
GEOLOGIA E TECTONICA DA PLATAFORMA (CRATON) AMAZÔNICA (PARTE DA AMAZÔNIA LEGAL BRASILEIRA)
}

\author{
RAIMUNDO MONTENEGRO GARCIA DE MONTALVÃO* P PEDRO EDSON LEAL BEZERRA*
}

\begin{abstract}
The aim of this paper is to present a synthesis of the geology and tectonics of the Amazonian Platform (Craton), including part of the Brazilian Amazon basin and comprising an area of approximately $4.000 .000 \mathrm{~km}^{2}$. The main concern of the authors was to reach a satisfactory uniformity in relation to the formal and informal lithostratigraphic units and the geotectonic terms.
\end{abstract}

INTRODUÇÃO O presente trabalho tem como objetivo retratar compilatoriamente a geologia da Plataforma (Craton) Amazônica nos domínios da Amazônia Legal Brasileira, onde se procura redefinir terminologias e unidades geológicas, e mostrar sinteticamente os resultados finais obtidos pelo Projeto RADAMBRASIL. Abrange uma área de aproximadamente $4.000 .000 \mathrm{~km}^{2}$, compreendendo os Estados do Pará, Amazonas, Acre, partes de Goiás e Mato Grosso, e os Territórios Federais do Amapá, Roraima e tratos de Rondônia, cujos principais centros populacionais são as cidades de Belém, Manaus, Rio Branco, Boa Vista, Macapá e Porto Velho.

Encontra-se na área em questão quase toda à Bacia Hidrográfica Amazônica, cuja drenagem principal é representada pelos rios Amazonas e Solimões, e seus afluentes: Tocantins, Xingu, Tapajós, Madeira, Juruá e Purus pela margem direita, e Jari, Erepecuru, Trombetas, Jatapu, Uatumã, Negro e Japurá pela margem esquerda.

Geomorfologicamente são identificadas diversas unidades morfo-estruturais, englobadas nos compartimentos de relevo, denominados Altos Planaltos, Planaltos Rebaixados, Pediplanos, Superfícies Sublitorâneas, Planície Amazônica e as Depressões. Os solos são representados predominantemente pelo latossolo amarelo, latossolo vermelho-amarelo e podzólico vermelho-amarelo, destacando-se as áreas conhecidas como Várzeas, com ocorrência de glei pouco húmico, glei húmico e solos aluviais.

Em termos de vegetação, são reconhecidas regionalmente na área seis Regiões Fitoecológicas, aparecendo com destaque a Floresta Ombrófila Densa Tropical e a Floresta Ombrófila Aberta Tropical, seguidas com menor distribuição areal pelas Savanas, Savanas Estépicas, Campinarama e a Floresta Estacio. nal Semidecidual Tropical. A Plataforma Amazônica tem como unidade crustal mais antiga o Complexo Basal (Complexo Xingu, G.G. da Silva et alii, 1974, e Complexo Guianense, Issler et alii, 1974). Os migmatito-gnaisses com faixas granuliticas foram forma- dos durante o Precambriano Inferior (Arqueano) a Médio, e rejuvenescidos no Precambriano Superior. No Precambriano Médio, quiçá Inferior (Arqueano), a crosta foi fragmentada com formação de estruturas alongadas, e deposição de seqüências vulcano-sedimentares e sedimentares, representadas pelo Cinturão Metamórfico Vila Nova-Jari, Cinturão Metamórfico Serra dos Carajás e, possivelmente, os Cinturões Metamórficos Cauarane e Tunui. Estes cinturões não foram bem datados, por isto acredita-se em uma idade mais jovem para o Cinturão Metamórfico Tunui. Após a formação destes tectonitos, menciona-se que o movimento vertical foi mais atuante, com falhamentos em blocos, e deposição da Formação Rio Fresco (Barbosa et alii, 1966 constituindo uma sequiência vulcano-sedimentar), acompanhada de intrusões graníticas (Granito Serra dos Carajás, de G. G. da Silva et alii, op. cit.). Porém, tais eventos são inexpressivos diante do intenso vulcano-plutonismo denominado de Grupo Uatumã (Série Uatumã, de Oliveira e Leonardos, 1943, com idade de 1900 m.a. - 1600/1500 m.a.). Continuando os movimentos de blocos houve formações de horsts e grabens onde depositaram-se espessas pilhas de sedimentos representadas pelo Grupo Roraima (Reid, 1972 entre 2000 m.a. - 1500 m.a.) e Formação Gorotire (Barbosa et alii, op. cit. com idade menor que $1850 / 1600$ m.a.), seguidas pelo Magmatismo Básico Tipo Pedra Preta (2000 m.a. - 1500 m.á.), e a sedimentação da Formação Mutum-Paraná (Lobato et alii, 1967) e Grupo Beneficente, de Almeida e Nogueira Filho, 1959, $1<1700 /$ $1600>1400$ ). Recorrência de magmatismo é registrada com intrusões do Sienito Cachorro (Oliveira et alii, 1975, 1460 m.a.), Granito Tipo Surucucu (1590 m.a. -1350 m.a.) e Granito Tiquié (Pinheiro et alii, 1976,1500 m.a.). Novamente a plataforma é reativada com formações de grabens e sedimentação da Formação Dardanelos (Almeida e Nogueira Filho, op. cit., com idade entre 1400 - 1200 m.a.), Formação Prosperança (Paiva, 1946 com idade mínima de 1400 m.a.), Formação Prainha (Almeida e Nogueira Filho, op. cit.)

*MME - DNPM - Proieto RADAMBRASIL - Av. Universitária, 444 - Goiânia -... Goiás - Brasil 
e Formação Cubencranquém (Barbosa et alii,op. cit.), sucedidas por intenso magmatismo básico e/ou ultrabásico, intermediário e ácido, representado pelo Vulcanismo Básico Tipo Arinos, (1400-1200 m.a.), Vulcanismo Básico Tipo Ciriquiqui (1372 e 1366 m.a.), Vulcanismo Básico Tipo Suretama, Granito Tipo Serra da Providência (Montalvão et alii, 1979a entre 1400-1200 m.a.), Granito Tipo Velho Guilherme (1380 m.a.) e Sienito Serra Acari (Fernandes e Morais, 1975).

O magmatismo ácido-intermediário, assinalado após isso, constitui o Sienito Canamã (Silva e Issler, 1974 com idade de $1175 \pm 30$ m.a.), o Sienito Teotônio (1250 - 950 m.a.) e o Sienito Guariba (100 m.a.), seguido dos Granitos Tipo Rondonianos (1152 \pm 38 m.a.), Efusivas Ácidas do Caripunas (Leal et alii, 1978 com idade de $1040 \pm 44$ m.a.), do Sienito Mutum (Montalvão e Abreu, 1975) e do Grupo Guajará-Mirim (Leal et alii, op. cit.), este representado por arenitos e vulcânicas básicas (idade mínima 1000 m.a.). Acredita-se que o último evento Precambriano com sedimentação seja representado pela Formação $\mathrm{Pi}$ menta Bueno (Leal et alii, op . cit.). No fim do Precambriano ou início do Paleozóico, houve a edificação da Sinéclise (Bacia) do Amazonas com sedimentação do Grupo Urupadi (D. B. dos Santos et alii, 1975), subdividido nas formações Trombetas (Derby, 1898), Maecuru (Derby, 1877) e Ererê (Hartt, 1896), depositado no intervalo Ordoviciano Superior a Mesodevoniano. Ainda no Devoniano, intrusão básica é registrada pela Formação Taiano de Amaral, 1974, datada em $360 \pm 22$ m.a., sendo que nos domínios da bacia, segue-se a deposição dos sedimentos da Formação Curuá (Derby, 1877 no Eocarbonífero). O Grupo Tapajós (D. B. dos Santos et alii, op. cit.), composto pelas formações Monte Alegre (Freydank, 1957), Itaituba (Hartt, 1896) e Nova Olinda (Kristler, 1954), é depositado no Pensilvaniano. Neste período, na baixa do Acre, deposita-se a Formação Formosa (Leite, 1958). Nos domínios das Folhas SC.20 Porto Velho, SC.21 Juruena e SC. 22 Tocantins, cobertura tabular, provavelmente permo-carbonifera, faz-se presente. No fim do Paleozóico e no Mesozóico, rochas magmáticas básicas, são representadas pelo Vulcanismo Básico Tipo Penatecaua, Cururu e Cassiporé. No Triássico e Jurássico-Cretáceo, manifesta-se um vulcanismo básico nos domínios do Graben do Takutu, denominado de Formação Apoteri com sedimentação associada (Formação Takutu). Intrusões alcalinas representadas pelo Sienito Catrimani (Santos e Salas, 1974) e provavelmente pelo Carbonatito Seis Lagos (Pinheiro et alii, op . cit.) e Alcalina "Maecuru" (Montalvão, 1976) é registrada no Cretáceo. Na bacia do Acre, depositam-se as unidades cretácicas (formações Moa, Rio Azul e Divisor de Moura e Wanderley, 1938). Seguem-se as Coberturas Sedimentares Cenozóicas e Sedimentos Aluvionares Recentes.

GENERALIDADES Almeida (1967) estudou as plataformas brasileiras caracterizando-as em duas Bai- calianas, as quais, denominou de Guaporé e São Francisco. Suszczynski (1969) e Ferreira (1969), introduziram a denominação de Plataforma Amazônica. Suszczynski (op. cit.) dividiu a Plataforma Amazônica en dois núcleos cratônicos denominados das Guianas e do Brasil Central. Issler (1977), conserva o termo Craton do Guaporé para a megaporção a sul da Sinéclise (Bacia) do Amazonas e considera como Craton Guianês a porção situada a norte. Outros termos como Escudo das Guianas e Escudo do Guaporé, têm sido usados na literatura geológica. Suszczynski (1970), divide a Plataforma Amazônica em três fases: Embasamento Cristalino (Pré-Cambriano); Fase Geológica Intermediária (Pré-Cambriano Superior ao Siluriano) e Cobertura Sedimentar Não Dobrada (Devoniano ao Terciário). Hasui, Abreu e Silva (1977), empregam o termo Craton Amazônico. Almeida (1978), usou a denominação de Craton Amazônico como sinônimo de Plataforma Amazônica no sentido de Ferreira (1972), bem como propõe o abandono dos termos Craton Guianês e Craton do Guaporé.

Vários autores tentaram classificar essa unidade geotectônica, sem conseguirem esboçar seu limite adequadamente. Assim sendo, usa-se o termo Plataforma Amazônica, como já citados por Ferreira (op. cit.) e Suszczynski (op. cit.) sem considerá-la como contendo os dois núcleos cratônicos admitidos por este último, e não Craton Amazônico de Hasui, Abreu e Silva (op. cit.) e Almeida (op. cit.). Plataforma e craton, são usados como sinônimos, e no sentido de Salop e Scheinmann (1969), correspondem a qualquer grande porção da crosta continental, limitada por cinturões dobrados ou às vezes por oceanos, caracterizados por estabilidade tectônica durante grandes períodos, homogeneidade tectônica geral (apesar das estruturas internas complexas e os diferentes tempos de formação de suas partes isoladas), e ausência de movimentos de gradientes elevados. Embora se tome como modelo esta definição, acredita-se que essa unidade de expressão continental contenha também cinturões metamórficos no seu interior. A Plataforma Amazônica, tem limites, ao norte com o oceano Atlântico e parte da Cordilheira Andina, ao sul e leste com os cinturões metamórficos "Paraguai-Cuiabá" e Tocantins-Araguaia (Silva et alii, 1974) ou "geossinclíneo Paraguai-Araguaia" de Almeida (1967); noroeste, sudoeste e oeste, com a Cordilheira Andina e a nordeste com o oceano Atlântico; a sudeste o limite é confuso, talvez devido a falta de melhor caracterização do Maciço Central de Goiás (Almeida, 1967), ou a incerteza se as seqüências que constituem o Grupo Araxá (Barbosa, 1955) e o Grupo Baixo Araguaia (Hasui, Abreu e Silva, op. cit.) ou Super Grupo Baixo Araguaia (Abreu, 1978) são realmente diferentes ou constituem um único cinturão metamórfico que se prolonga do sul do Pará em direção a Goiás e Minas Gerais. Aqui coloca-se duvidosamente esta parte da Plataforma Amazônica margeada pelos metamorfitos do Grupo Araxá, sendo as 
seqüências vulcano-sedimentares de Crixás, Pilar, Hidrolina, Mara Rosa, etc., que foram definidas como greenstone belts por Dani e Ribeiro (1978) e Saboia (1979), consideradas como cinturões metamórficos dentro da plataforma. Esses limites estão baseados a grosso modo nos mapas ao milionésimo dos projetos RADAMBRASIL e Carta Geológica do Brasil ao Milionésimo, e no Mapa Tectônico da América do Sul (Almeida et alii, 1978). Usar-se-á também o termo cinturões metamórficos, em vez de cinturões dobrados (cinturões geossinclinais ou cinturões móveis) uma vez que estes apresentam várias definições, muitas vezes pcuco compreensíveis, na literatura geológica. Os termos cinturão dobrado ou cinturão geossinclinal não seriam aconselháveis no sentido de que muitos geólogos os considerarem como entidades que sempre margeiam as antigas plataformas.

O termo "cinturão metamórfico" é aqui usado em substituição aos geossinclinais do conceito clássico de Stille (1930, apud Auboin, 1965), Kay (1951) e outros (apud Auboin, op. cit.), que chamaram de ortogeossinclinais, os quais não ocorrem na Plataforma Amazônica na área em questão. Para esses, o termo geossinclinal (ortogeossinclinal) são fases contendo um sulco eugeossinclinal e uma ruga eugeanticlinal e um sulco miogeossinclinal e uma ruga miogeanticlinal, e posição intercratônica (interplataformal) ou entre a plátaforma e o oceano. Pela localização dos cinturões citados no trabalho em pauta, pode-se observar que os cinturões metamórficos Serra dos Carajás, Vila Nova-Jari, "Cauarane?" e Tunui, apresentam posições intracratônicas (Intraplataformal). Já o Cinturão Tocantins-Araguaia e o Cinturão Paraguai-Cuiabá (?) ambos constituindo a Faixa Paraguai-Araguaia (de Almeida, 1965), ocupam posição aparentemente interplataformal, isto é, separam a Plataforma Amazônica da Plataforma do São Francisco. Não se considera também o termo greenstone belts para os cinturões Serra dos Carajás e Vila Nova-Jari por falta de melhor conhecimento das unidades, bem como por se achar que as seqüências vulcano-sedimentares com formações ferríferas do tipo bandeada associadas, que ocorrem nestes dois cinturões não foram bem estudadas para serem enquadradas em modelo tão exigente como o proposto por Anhaeusser et alii (1969). Por exemplo, o Cinturão Metamórfico Serra dos Carajás, nos domínios da serra homônima apresenta em sua totalidade rochas metamórficas constituídas de sequiências paleovulcânicas e formação ferrífera, o mesmo ocorrendo na Serra do Inajá. Já no Cinturão Vila Nova-Jari, em alguns locais, a sequiência é mais rica em pelitos e carbonatos, sendo a sèquêencia ultrabásica bem localizada em relação ao cinturão. Apesar de não ter sido encontrado, até o presente estágio de conhecimento, nesses cinturões, sequiências tão completas como os greenstone belts da África do Sul, Canadá e Austrália, não se exclui a possibilidade dos mesmos estarem incluídos nesta categoria.
Quanto ao termo cinturão móvel (Mobile belt) também não foi aqui usado por já o ser em várias definições até certo ponto contraditórias. Anhaeusser et alii (1969): Mobile belt is used to describe the younger, linear, metamorphic belts which tend to surround the ancient cratonic nucleous of shield areas and which are characterized by high - grade metamorphism, granitization and often by transcurrent dislocation ... the term mobile belt is used here to replace orogenic belt, which is considered to imply a geotectonic evolution involving geosynclines and orogeny - something that has never been satisfactorily established.

Estes autores consideram como "cinturão móvel" zonas lineares, mais jovens, que margeiam os núcleos cratônicos, representados por tectonitos de alto grau metamórficos, granitizados, com atuação de processo de reomorfismo e anatexia baseados principalmente nos modelos da África e Canadá. O sentido crítico do termo está no simples fato de que estes cinturões são compostos de rochas de alto grau metamórfico, altamente granitizadas, sendo estas rochas aqui entendidas como migmatitos, granitóides de anatexia e metassomáticos, suítes básicas ultrabásicas metamorfisadas, gnaisses, granulitos, etc. Tais rochas nos parece apresentarem as mesmas características "estruturais" e petrográficas das que constituem o "complexo basal" ou "núcleo cratônico" como referido por eles, daí se achar que o critério seria simplesmente geocronológico, pois acredita-se que estas duas entidades não seriam facilmente separadas por geologia de campo e informações petrográficas. Outro motivo é o uso do termo, pois aqui usa-se craton como sinônimo de plataforma sendo portanto uma entidade que envolve o escudo e não envolvido por este, como considera (Anhaeusser et alii, op. cit.). Por outro lado, Kratz e Glebovitski (1972), citam cinturões móveis (Mobile Belts) da Rússia com presença de xisto verde de baixa temperatura no Pré-Cambriano Superior e Fanerozóico.

Sendo assim, o termo cinturão metamórfico é usado neste trabalho no sentido de representar faixas lineares, dobradas, metamórficas, submetidas a meta morfismo regional das fácies xisto verde e anfibolito ou xisto verde, formando dobras holomórficas (contínuas) constituidàs por flexuras, com desenvolvimento de xistosidade, clivagem ardosiana, crenulações de clivagem, clivagens de fraturas, etc. Essas características estruturais e petrográficas bem pronunciadas diferem bastante das rochas que constituem o "complexo basal" cujo ultrametamorfismo foi responsável por granitização e reomorfismo formando estruturas foliadas mais grosseiras e/ou dando um aspecto mais homogêneo às rochas. Esses cinturões metamórficos, constituídos por seqüências vulcano-sedimentares e sedimentares foram denominados de Cinturão Metamórfico Vila Nova-Jari, Cinturão Metamórfico Serra dos Carajás (inclui Serra do Inajá), Cinturão Metamórfico Cauarane (?), Cinturão Metamórfico Tunui e inclui-se 
a Formação Tocandera. Devido a falta de maiores exposições de rochas, seus contatos com os migmatitos e anatexitos do "complexo basal", às vezes são de dificil precisão. Porém acredita-se que tanto o Cinturão Metamórfico Tunui, como o Cinturão Metamórfico Serra dos Carajás (área da Serra do Inajá) não foram afetados por granitização em suas bases e se isso aconteceu, no último, foi muito localizado. Enquanto que no Cinturão Metamorfico Vila Nova-Jari parece ter sido granitizado localmente, e provavelmente com um pouco mais de intensidade devido o grau metamórfico a que foi submetido.

Como justificado acima, usa-se o termo cinturão metamórfico no sentido mais geral e se tem como exemplos os trabalhos de Miyashiro (1973) e Kratz e Glebovitsky (op. cit.).

\section{ESTRATIGRAFIA Propor uma estratigrafia para} a Plataforma Amazônica na área em epígrafe é tarefa dificil, devido o grande número de eventos e unidades litoestratigráficas formais e informais. Sabe-se também que os dados disponíveis da região são poucos, sendo os mapas de reconhecimento (maioria dos casos) restritos às poucas áreas de acesso. Assim se procura fazer uma descrição resumida e uma tentativa de correlacionar as unidades litoestratigráficas existentes.

A Plataforma Amazônica na área, tem como unidade crustal mais antiga o "complexo basal" constituido do complexo granito-migmatito-granulito, denominado de Complexo Guianense (Issler et alii, 1974) e Complexo Xingu (Silva et alii, 1974). Esta unidade litoestratigráfica apesar de sua complexidade estrutural, é bastante homogênea, com estruturas formadas por fluxo de materiais graniticos durante os processos de reomorfismo e anatexia. É constituída dos mais diversos litotipos, formados nas fácies granulitos e anfibolitos, sendo seu polimetamorfismo evidenciado por diversas superfícies penetrativas, e os efeitos diaftoréticos marcados pela presença de minerais da fácies xisto verde como clorita, sericita, epídoto, etc., dentro de rochas migmatíticas e granitóides de anatexia. As rochas que constituem o "complexo basal" foram formadas ao que tudo indica no Pré-Cambriano Inferior (Arqueano) a Médio, apesar da maioria das isócronas $\mathrm{Rb} / \mathrm{Sr}$ cairem dentro do Pré-Cambriano Médio a Superior, sendo as que caem neste último, ligadas, provavelmente, a processos de rejuvenescimentos isotópicos. Os valores obtidos para as referidas isócronas suscitaram inúmeras interpretações, mas procura-se aqui relatar seus valores sem entrar em maiores considerações sobre os mesmos. Deste modo, tem-se os seguintes resultados isocrônicos obtidos pelo método $\mathrm{Rb} / \mathrm{Sr}$, nas diversas áreas mapeadas pelo Projeto RADAMBRASIL: $1330 \pm 60$ m.a. (Folha SA.20 Manaus); $1515 \pm 25$ m.a. (Folha NA.19 Pico da Neblina); $1640 \pm 26$ m.a. (Folha SA.19 Içá); $1910 \pm 70$ m.a. (Folha SA.21 Santarem); $1787 \pm 33$ m.a. (Folha NA/NB.20 Boa Vista/Roraima); $1791 \pm 10$ m.a. (Fo- lha NA.21 Tumucumaque); $1470 \pm 54$ m.a. (Folha SC.20 Porto Velho); $1477 \pm 13$ m.a. (Folha SC.19 Rio Branco); $1864 \pm 60$ m.a. (Folha SB.22 Araguaia); $1797 \pm 90$ m.a. e $1684 \pm 40$ m.a. (Folha SC. $21 \mathrm{Ju}-$ ruena); 2750 m.a. e 2000 m.a. (Folha SC.22 Tocantins).

No Pré-Cambriano Médio e Inferior? (Arqueano), a crosta foi fragmentada, com formação de frar turas que atingiram ou não o manto, formando estruturas lineares, alongadas, controladas por falhamentos. Sobre estas estruturas afundadas ou afastadas, formadas no embasamento gnaisse-migmatítico, foram depositadas seqüências vulcano-sedimentares, com formação ferrífera associada e sedimentares, posteriormente dobradas e metamorfisadas nas fácies xisto verde a anfibolito e xisto verde.

Assim nos domínios da área ocupada pelas Folhas SB.22 Araguaia e SC.22 Tocantins, desenvolveu-se o Cinturão Metamórfico Serra dos Carajás. Referências sobre suas rochas são observadas em Parada et alii (1966) que estudando a região do rio Naja, afluente do Rio Fresco, formalizaram a Formação Tocandera composta de quartzitos e itabiritos, enquanto que Ramos (1967), Francisco, Silva e Araújo (1967) e Tolbert et alii (1970) correlacionaram-nas às "séries" Tocantins e/ou Araxá. CVRD/CMM (1972) denominam de Grupo Grão-Pará, as unidades ocorrentes na Serra dos Carajás, composto pela sequiência Paleovulcânica Inferior, Formação Carajás (Itabirito, minério de ferro lixiviado e intercalações e diques de rochas máficas) e seqüência Paleovulcânica Superior. Suszczynski (1972) dá uma série de evidências a favor da origem vulcânica do minério de ferro primário da Serra dos Carajás. Beisiegel et alii (1973) fazem interpretações estruturais e tectônicas, sobre as rochas da referida serra. Issler (1973) considera a Formação Tocandera (Parada et alii, op. cit.) como um fácies do Grupo Grão-Pará. G. G. da Silva et alii (1974), identificam duas faces orogênicas na área cratônica do Guaporé, sendo a responsável pelo estabelecimento do Grupo Grão-Pará ocorrido por volta de 1800 a 2000 m.a., baseados em datações de rochas básicas (K/Ar), e consideram metamorfismo do fácies xisto verde a anfibolito. Gomes, Cordani e Basei (1975) admitem a idade de 1960 m.a. para a fase sintectônica principal da orogenia Transamazônica, que estabeleceu rochas da fácies xisto verde na Serra dos Carajás. (*São posicionadas como pertencentes ao Cinturão Metamórfico Serra dos Carajás, as. rochas da Serra do Inajá), localiżadas na porção centro-norte da área da Folha SC.22 Tocantins. Ianhez e Montalvão (1978) e Montalvão et alii (1979b) apresentam algumas informações sobre a dita serra, sendo a mesma constituída

* As rochas da Serra do Inajá foram incluídas no Cinturão Metamórfico Serra dos Carajás por falta de maiores dados; talvez fosse mais viável considerar outro cinturão metamórfico (Cinturão Metamórfico Serra do Inajá). 
pór uma sequiência vulcano-sedimentar, metamorfisada na fácies xisto verde, raramente anfibolito, representada por ultrabásicas (serpentinitos), clorititos, clorita-xistos, meta-diorito pórfiro ou meta-andesito, andesito, itabirito, hornfels e mármore. Apresentam estruturas planares de baixo grau, tais como xistosidade, clivagem ardosiana e crenulações de clivagem: Esta estrutura constitui "remanescente" dentro das rochas migmatíticas e granitóides de anatexia, do "complexo basal" que apresenta idade isocrônica de referência $\mathrm{Rb} / \mathrm{Sr}$ de 2750 m.a. com razão inicial $\mathrm{Sr}^{87} / \mathrm{Sr}^{86}=0.704$. Considerando-se tal idade como Arqueana, aventa-se a possibilidade de tais rochas associarem-se ao "cinturão", que deste modo seria representante bem antigo da Plataforma Amazônica, assim como na Serra dos Carajás.

A norte da Sinéclise (Bacia) do Amazonas desenvolviam-se os Cinturões metamórficos Vila Noya-Jari, Cauarane? e Tunui, sendo este último provavelmente mais novo que aqueles. O Cinturão Metamórfico Vila Nova-Jari, foi primeiro descrito por Paiva (1946) próximo a Serra do Navio, cujas rochas foram englobadas sob a denominação de Série Vila Nova por Ackerman (1948). Tais rochas foram bem estudadas na Serra do Navio, Território Federal do Amapá, por Nagell e Silva (1961), Nagell (1962), Marrota et alii (1966) e Scarpelli (1966), tendo Lima et alii (1974) as denominado de Grupo Vila Nova em substituição ao termo "série" de Ackerman (op. cit.). É constituído por um conjunto de rochas de epi e mesozona, formando uma associação de. anfibolitos, quartzitos, mármores, granada-quartzitos, xistos granatíferos, sillimanita xistos, estaurolita xistos, formação ferrifera bandeada, formação manganesífera e rochas verdes e ultrabásicas, estruturalmente alinhadas na direção NW/SE (predominante). A base do Cinturão Metamórfico Vila Nova-Jari é constituída em geral de anfibolitos e quartzitos, mais raramente micaxisto, jazendo sobre as rochas do complexo basal. E possivel que tenha sido granitizada localmente, mas em alguns lugares isto não ocorre, pois observam-se quartzitos impuros, micaxistos com granada, biotita, sillimanita, estaurolita, etc., diretamente sobre os anatexitos, rochas essas que facilmente seriam granitizadas. Sua idade é admitida em 2090 m.a., baseada em isócrona $\mathrm{Rb} / \mathrm{Sr}$ de rochas da Serra do Navio, traçada com os dados de Hurley et alii (1968, apud Lima et alii, op. cit.). Apesar da isócrona $\mathrm{Rb} / \mathrm{Sr}$ de $2090 \mathrm{~m}$.a., sugere-se um trabalho de campo e geocronológico mais adequado, com a finalidade de comprovar ou não estrutura arqueana para o cinturão. O Cinturão Metamórfico Cauarane, corresponde ao Grupo Cauarane (Montalvão e Pitthan, 1974), sendo constituído de quartzitos, anfibolitos, micaxistos com quartzitos ferruginosos, responsáveis pela edificação da serra homônima localizada no canto NE da Folha NA.20 Boa Vista com direção NW/SE, ocorrendo também em outros sítios desta folha, e no extremo oeste da área da Folha NA.21
Tumucumaque. Uma única datação em anfibolito (K/Ar) acusou idade de $1920 \pm 20$ m.a. Duvidosamente posicionada como sincrônica aos cinturões metamórficos está a Formação (Grupo) Tocandera, Parada et alii, (op. cit.), ocorrente no extremo sul da área da Folha SB.22 Araguaia. Tal posicionamento resulta do fato de haver dúvida se esta unidade está ou não metamorfisada regionalmente, sendo que a maioria dos autores, entre eles, Parada et alii (op. cit.) e G.G. da Silva et alii (op. cit.), admitem a existência de metamorfismo dé baixo grau, tendo os últimos a colocado como ùm fácies do Grupo Grão-Pará, Cinturão Metamótfico Serra dos Carajás neste trabalho. João et alii (1975) a consideram como uma cobertura de plataforma sem metamorfismo regional. Segundo G. G. da Silva et alii (op. cit.) compõe-se de quartzitos, micaxistos, com foliação de direção WNW-ESE e NNW-SSE com mergulhos médios a fortes para sul e filitos enriquecidos com itabiritos. Quanto ao Cinturão Metamórfico Tunui (Grupo Tunui, de Montalvão e Fernandes, 1975) não se dispõe de datações diretas de suas rochas. É composto por uma sequiência de quartzitos micáceos, filitos, formação ferrífera bandeada e hematita, ocorrentes no extremo norte da Folha NA.19 Pico da Neblina e Noroeste da Folha SA.19 Içá, cortadas por rochas vulcânicas que apresentam idade convencional $\mathrm{Rb} / \mathrm{Sr}$ de 1500 m.a. Mostra uma contribuição psamítica muito grande e o vulcanismo básico-ultrabásico sincrônico está ausente, tendo sido caracterizado como ambiente miogeossinclinal por Montalvão (1976).

Após a formação desses tectonitos cujo principal agente formador, provavelmente são forças dos tipos de compressão e crumpling, que vão esmorecendo e a força vertical se torna atuante com formação de falhamentos em blocos, edificando pilares e bacias, daí se formarem algumas bacias isoladas, acompanhadas de intrusões, que na área em epígrafe são representadas provavelmente por unidades como Formação Rio Fresco e o Granito Tipo Serra dos Carajás. A Formação. Rio Fresco é uma unidade litoestratigráfica definida por Barbosa et alii (1966) para denominar uma sucessão que começa por uma ardósia cinzenta carbonosa, seguidas de ardósias cor de cimento ou cinza-azuladas, intercaladas por inúmeras camadas e bancos de arcósios, cinzento-esverdeados a cinzento-escuros, às vezes micáceos, intercalados com um vulcanismo andesítico. IDESP (1972) considera como Formação Rio Fresco, somente a porção sedimentar, sendo a parte vulcânica englobada sob a denominação de Formação Sobreiro. G.G. da Silva et alii (op. cit.) colocam esta unidade como.basal do Grupo Uatumã e propõem sua subdivisão nos membros Azul e Naja, estando o primeiro exposto no interior do sinclinório dos Carajás, área do Igarapé Azul, composto por camadas de conglomerado cinza-claro incluindo seixos de quartzo e quartzitos com matriz arenosa e argilosa, arenito creme-esverdeado mau selecionado (argiloso, micáceo 


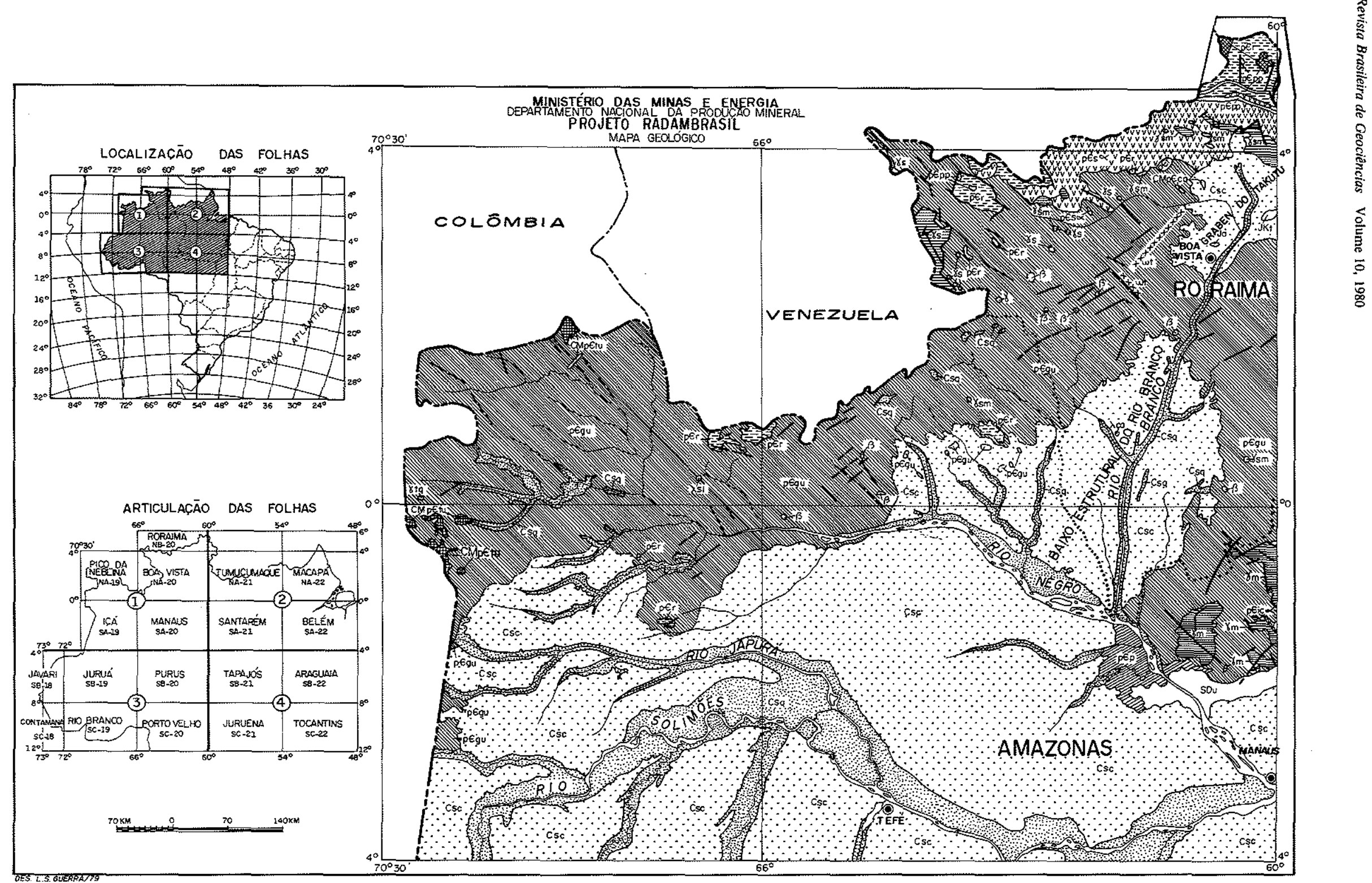

Folha 1 


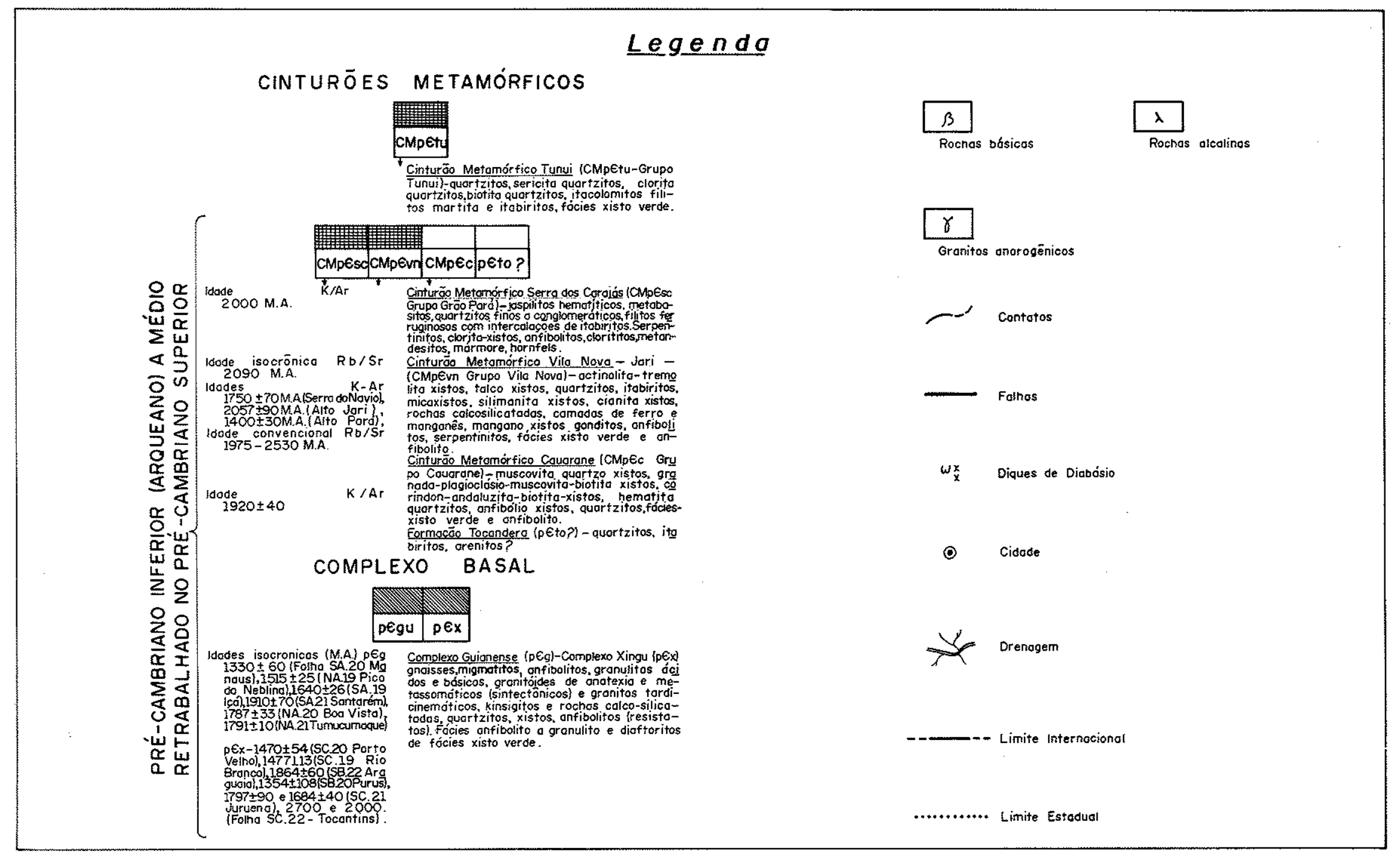




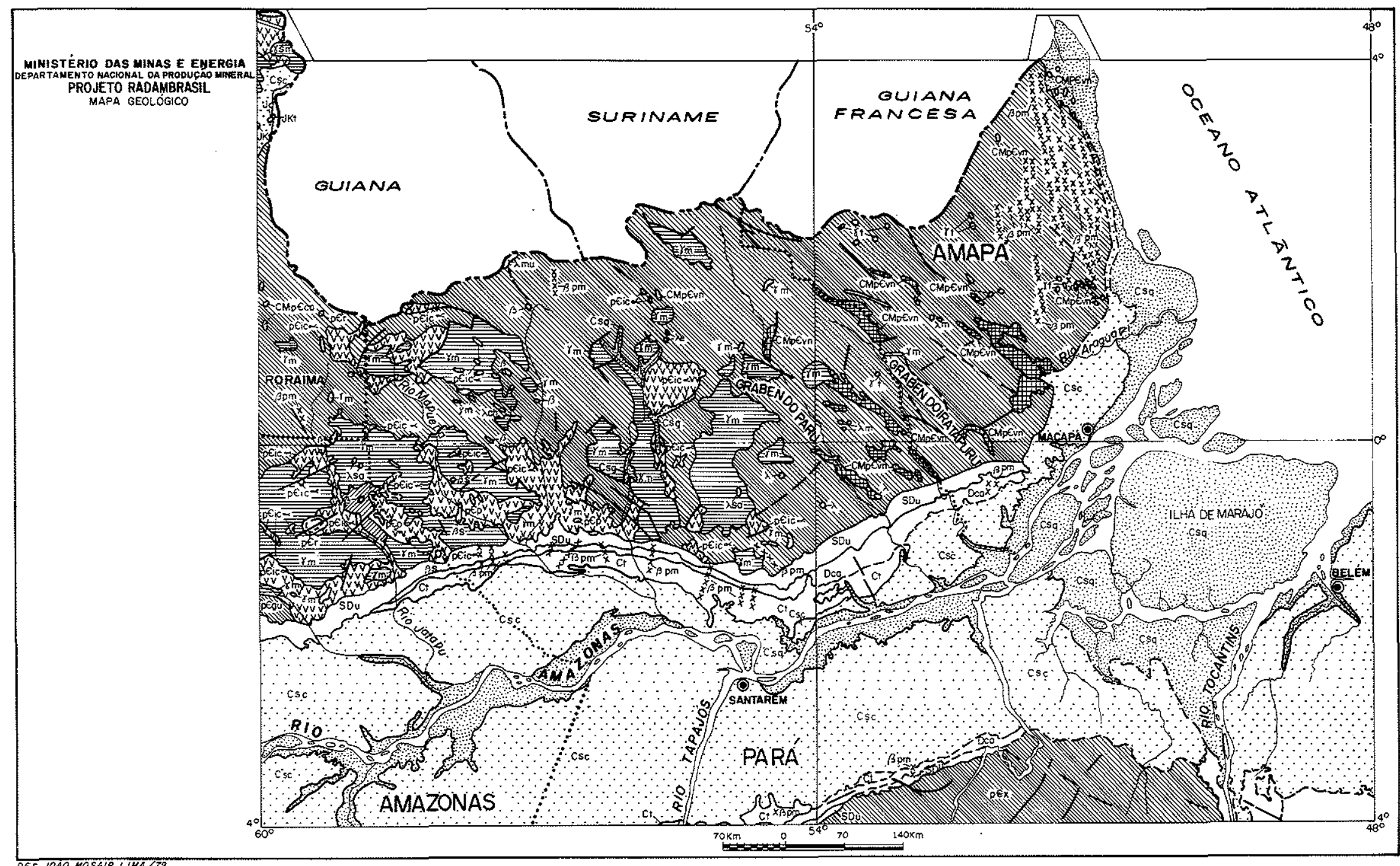

Folha 2 


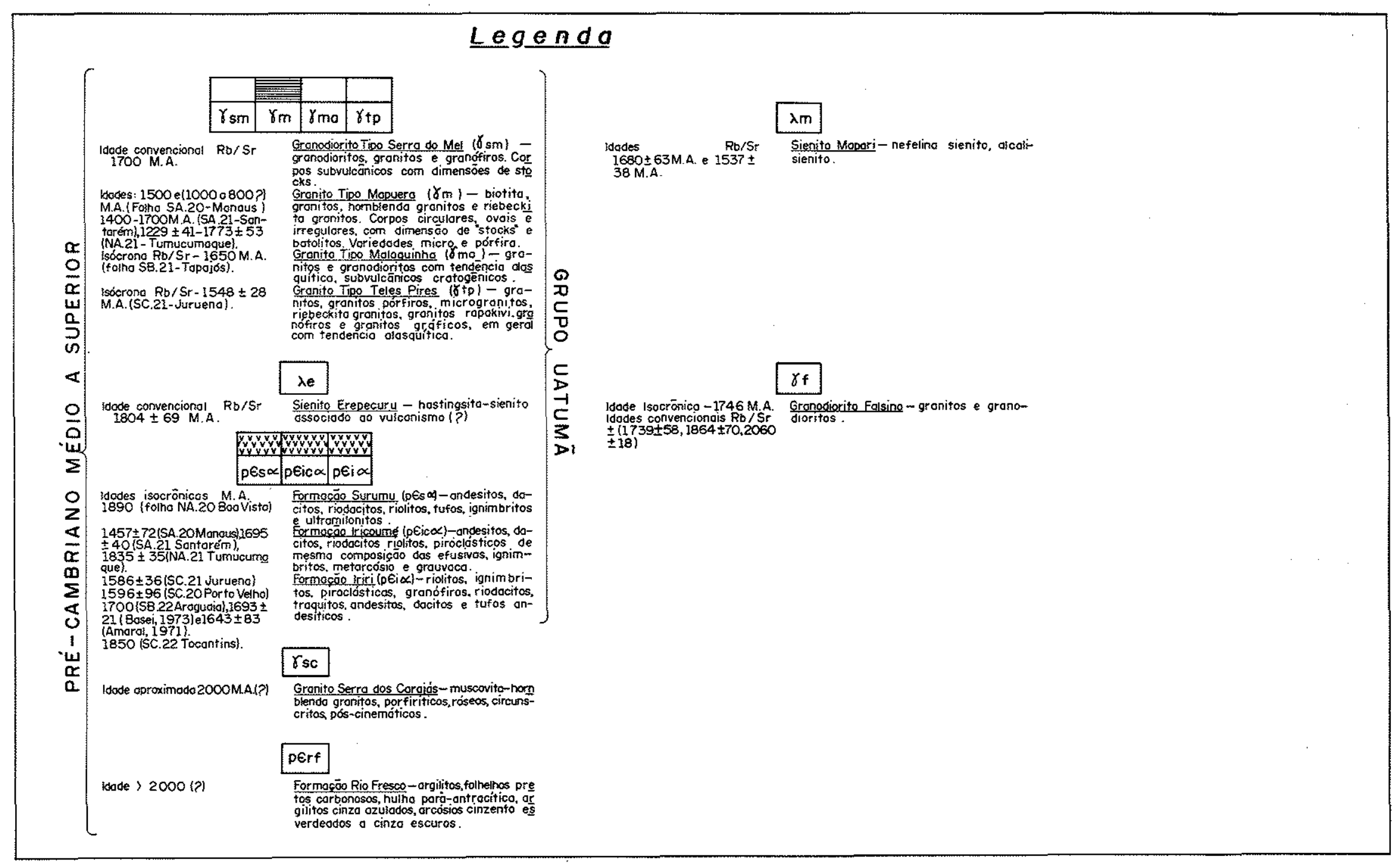




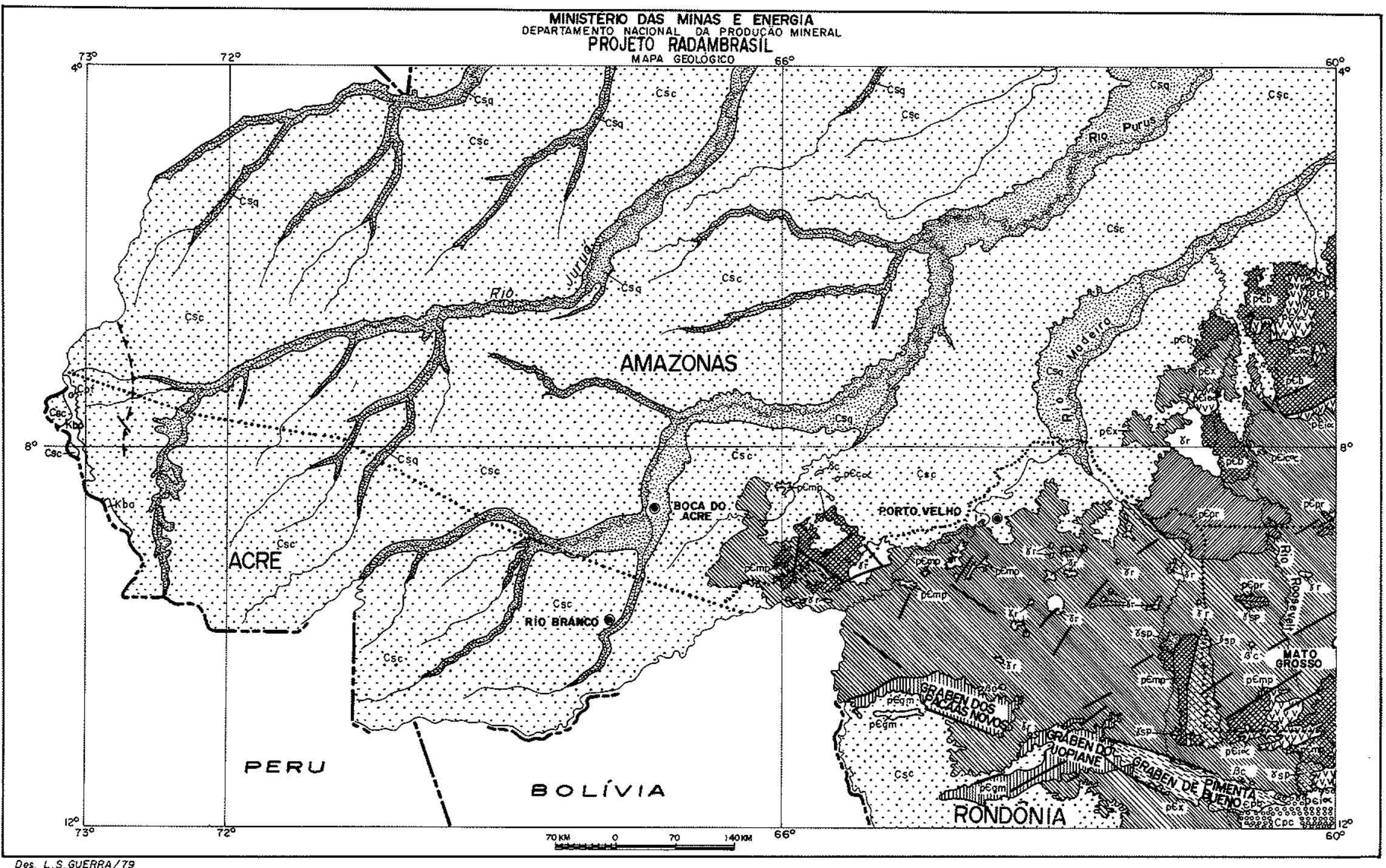

Folha 3 


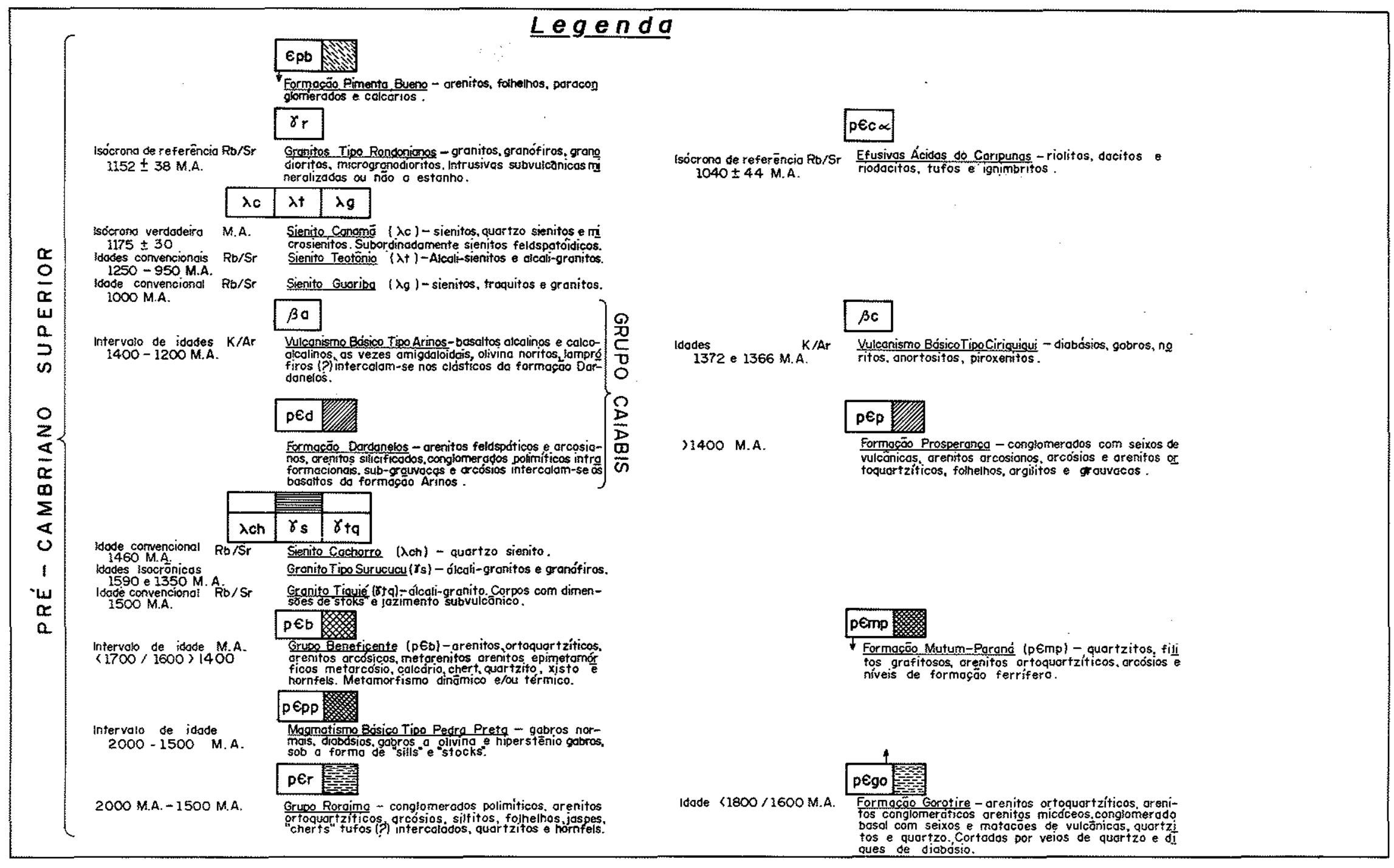

OBS. Legenda continua na página 14 (Folha 3a) 


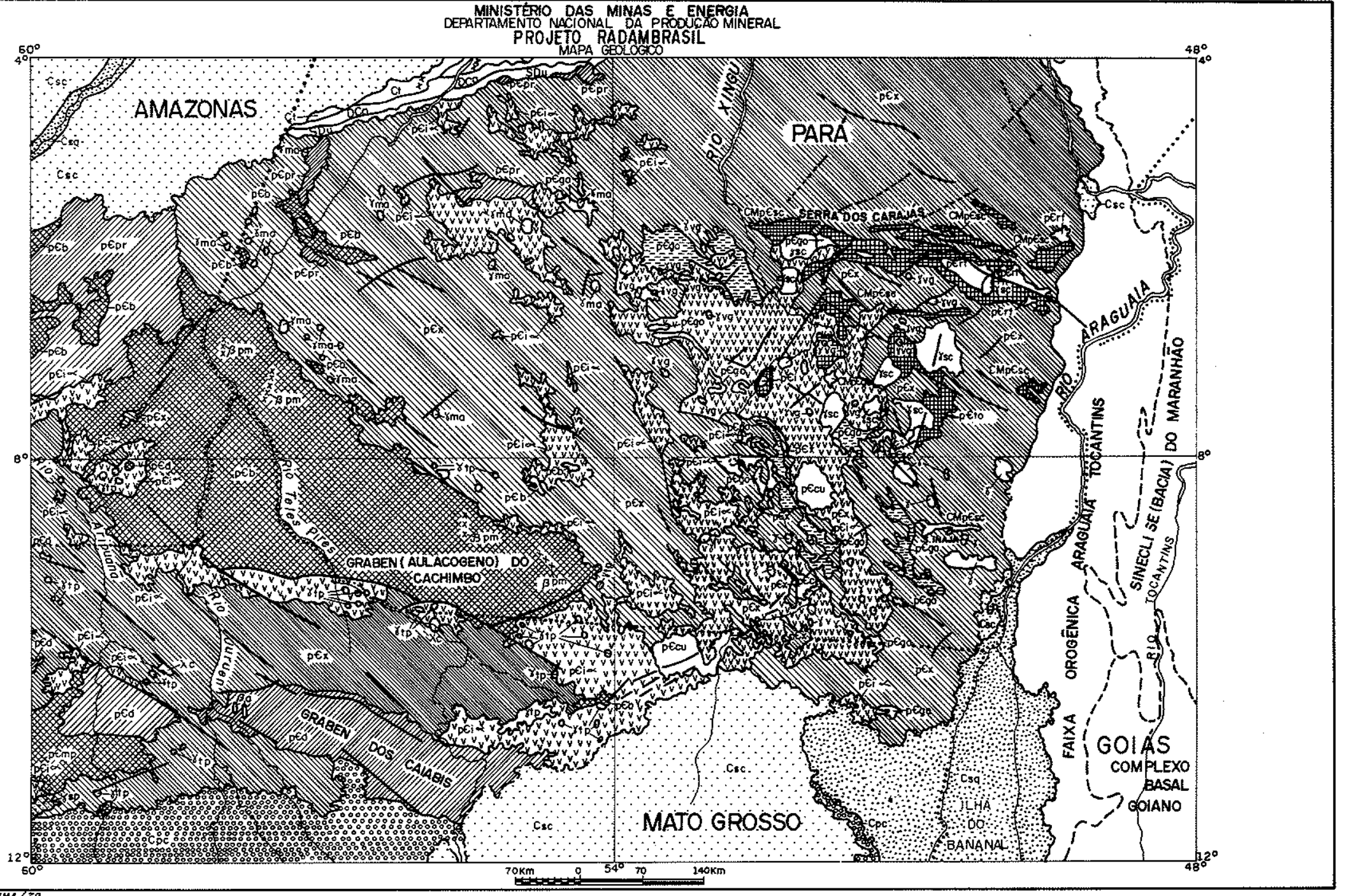

Folha -4 


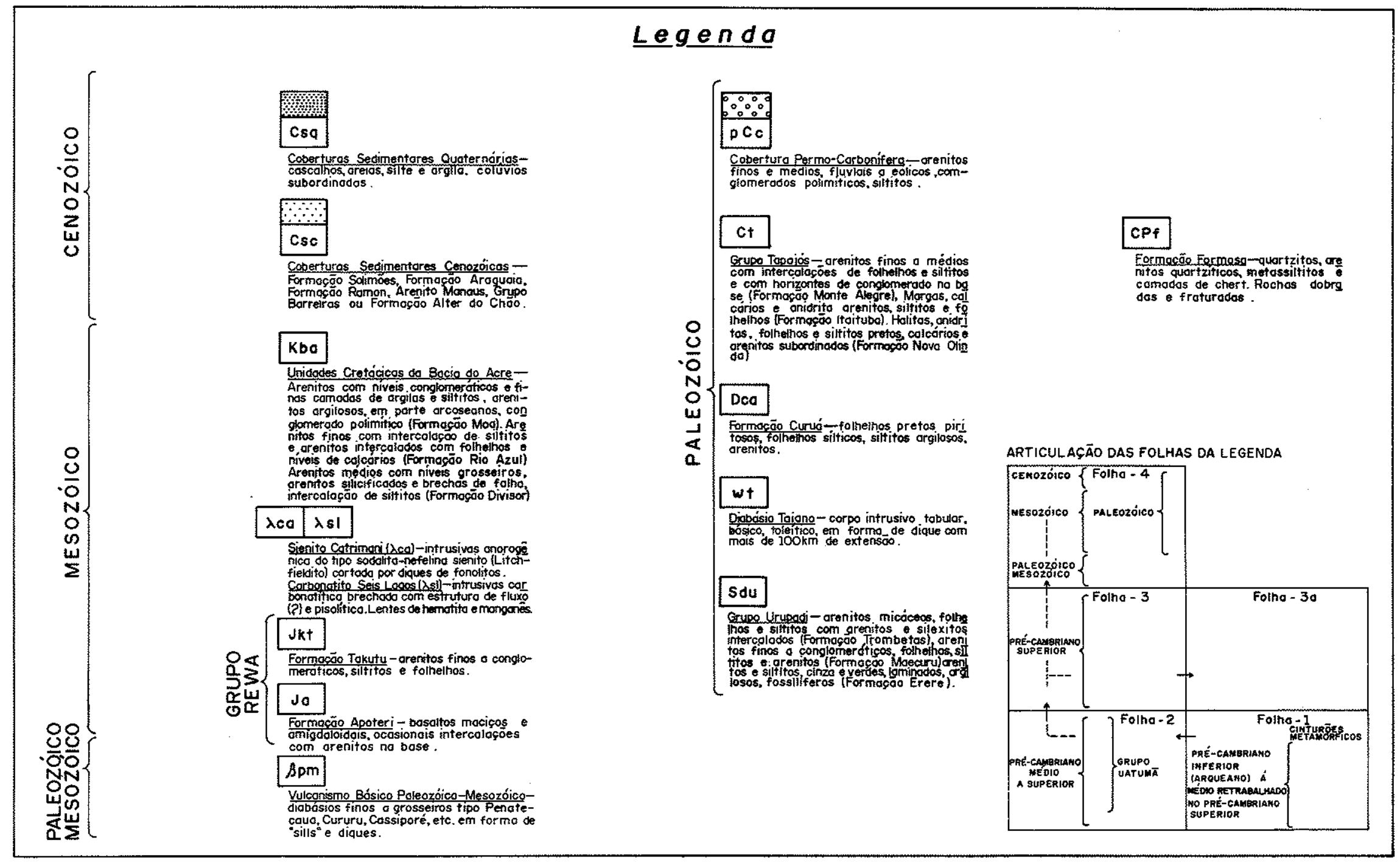




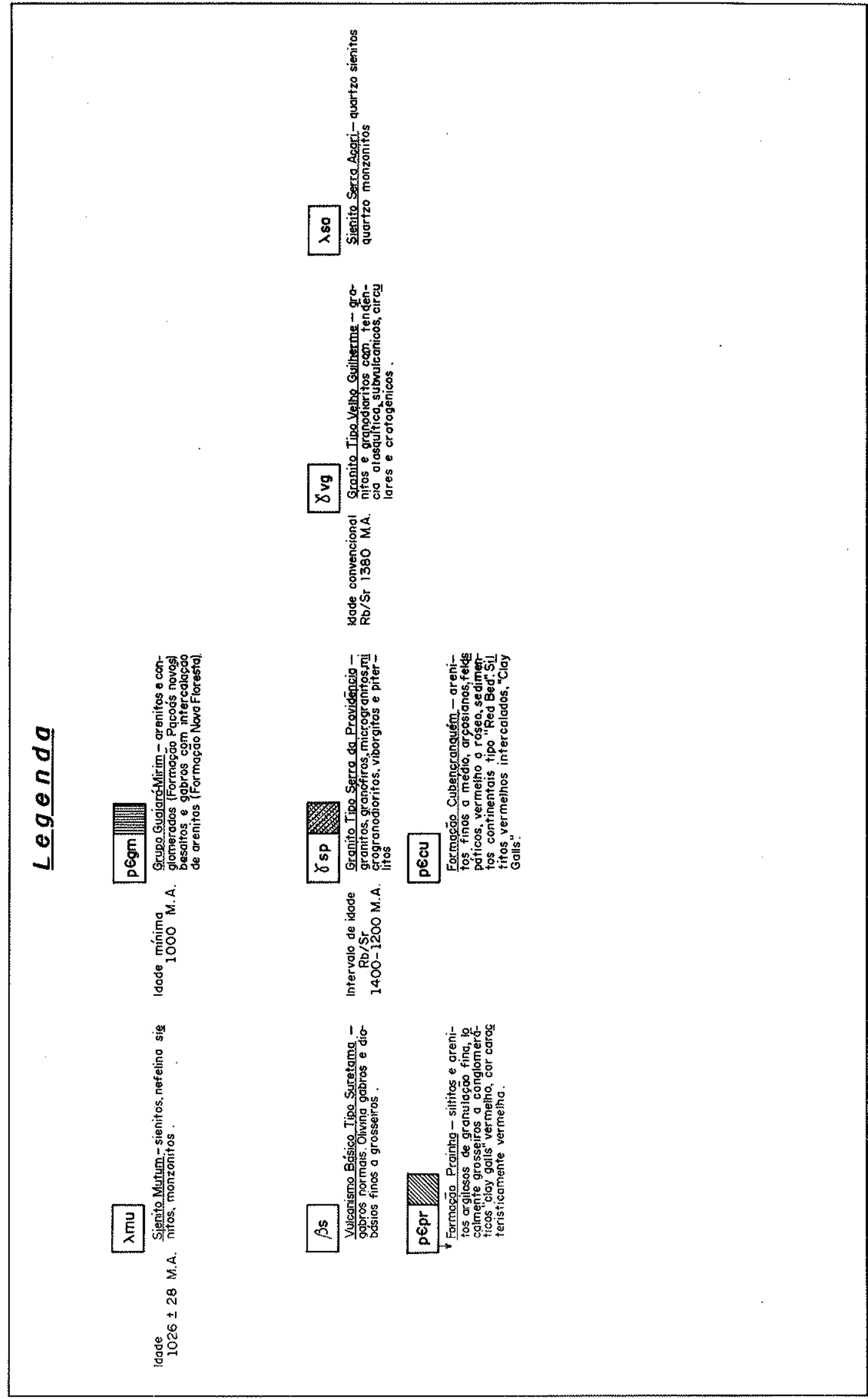


feldspático) e folhelhos pretos, manganesiferos e carbonosos nas camadas superiores. O Membro Naja, expor-se-ia no interior do sinclinório da Tocandera, constituído por sucessivas alternâncias de camadas de arenitos arcoseanos, siltitos, grauvacas, folhelhos ardosianos cinza-esverdeados, por vezes micáceos, carbonosos e calcíferos. Estes mesmos autores (op. cit.) identificaram oito maciços, com expressão amebiforme a grosseiramente circular, denominados de Granito Serra dos Carajás, intrusivos na base da Formação Rio Fresco, cujas idades radiométricas acusaram 1810 m.a. (K/Ar) e 1708 m.a. (Rb/Sr), e colocados como anteriores ao vulcanismo Uatumã, que na área da Folha SB.22 Araguaia apresenta isócrona $\mathrm{Rb} / \mathrm{Sr}$ de 1700 m.a. Um corpo granítico relacionado ans Tipo Serra dos Carajás, foi tido duvidosamente por Knup (1971) como intrusivo no Grupo Grão-Pará e denominado informalmente de "Granito Central". Além deste tem-se o Granito da Seringa (Hidroservice/ SUDAM, 1973). CVRD/CMM (1972) encontram indícios de metamorfismo no ponto de contato entre o granito e o arenito, então considerado como Formação Gorotire, mas que segundo G. G. da Silva et alii (op. cit.), em verdade pertence ao Membro Azul da Formação Rio Fresco.

Porém, é digno de nota que o prịncipal evento tectono magmático registrado nesta fase de movimentação, é o vulcano-plutonismo ácido a intermediário com sedimentos locais denominados de Grupo Uatumã. Este evento é marcante e foi posicionado no intervalo de 1900-1600/1500 m.a., sendo dificil de precisar e separar o plutonismo Uatumã, dos eventos anteriores e logo posteriores a ele. As rochas desta unidade litoestratigráfica foram primeiro descritas por Albuquerque (1922), que ao contrário do que se tem pensado não lhes atribuiu nenhuma denominação formal ou mesmo informal. Oliveira e Leonardos (1943) chamaram estas rochas de Série Uatumã. Ferreira (1959) apresentou importantes contribuições, principalmente quanto a sua constituição litológica. Barbosa (1966) foi o primeiro a chamar de Grupo Uatumã, a um vulcanismo por ele descrito no médio Tapajós. Caputo et alii (1971) redefiniram o conceito Uatumã, até então adotado pela Petrobrás, que considerava como pertencentes a esta unidade litoestratigráfica os sedimentos sotopostos a Formação Trombetas. Rambrab e Santos (1974) correlacionaram o Grupo Uatumã aos grupos Burro-Burro e Kuyuwini da Guiana, a Formação Surumu de Roraima, e a Associação granítico-vulcânica do Suriname. A norte da Sinéclise, o Grupo Uatumã está representado pelas formações Surumu e Iricoumé, e suas intrusivas comagmáticas associadas. A Formação Surumu (Barbosa e Ramos, 1959) é constituída de rochas vulcânicas e piroclásticas ácidas e intermediárias com dobras locais e ampla distribuição, formando uma faixa de direção aproximada $\mathrm{E}-\mathrm{W}$, no extremo Norte do Território Federal de Roraima, prolongando-se pelos territórios da Venezuela, Re- pública da Guiana e Suriname. A idade isocrônica de reterência $\mathbf{R b} / \mathrm{Sr}$, obtida por Basei (1975) acusou 1890 m.a. Sua equivalência ao Grupo Uatumã foi proposta por Montalvão (1974), apoiado em dados petrográficos dinamometamorfismo, alteração hidrotermal, datações radiométricas e posição estratigráfica. A Formação Iricoumé (Oliveira et alii, 1975) é constituída por riolitos, dacitos, riodacitos, andesitos e piroclásticas ocorrendo nas Folhas NA.21 Tumucumaque, SA.21 Santarém e SA.20 Manaus, apresentando idades isocrônicas diferentes em cada área considerada como $1.457 \pm 72 \mathrm{~m}$ :a. na Folha SA.20 Manaus, $1695 \pm$ \pm 40 m.a. na Folha SA.21 Santarém e $1835 \pm 35$ m.a. na Folha NA.21 Tumucumaque.

Como representante do Grupo Uatumã a sul da sinéclise, encontra-se a Formação Iriri e suas intrusivas subvulcânicas associadas. Esta formação foi definida por SUDAM (1972), constituída de vulcanitos ácidos, tufos e ignimbritos, com presença marcante no leito do rio Iriri, cabendo a G.G. da Silva et alii (op. cit.) sua inclusão no Grupo Uatumã. D.B. dos Santos et alii (op. cit.) e G.H. Silva et alii (no prelo) estenderam esta unidade litoestratigráfica para áreas das Folhas SB.21 Tapajós e SC.21 Juruena, sendo que Leal et alii (1978), na Folha SC.20 Porto Velho a denominaram de Formação Roosevelt o que absolutamente não concordamos. Pessoa et alii (1977) a elevaram a categoria de Sub-grupo constituída pelas formações Aruri e Salustiano. As idades isocrônicas para a Formação Iriri do mesmo modo que a Formação Iricoumé apresentam-se diferentes em cada área considerada. Desse modo, tem-se $1586 \pm 36$ m.a., $1596 \pm$ \pm 96 m.a., 1700 m.a. e 1850 m.a., nas áreas das Folhas SC.21 Juruena, SC.20 Porto Velho, SB.22 Araguaia e SC. 22 Tocantins, respectivamente. Acrescenta-se ainda resultados obtidos por Basei (1973) em $1693 \pm 21$ m.a. e os de Amaral (1971) em $1645 \pm 83$ m.a.

No tocante às fases subvulcânicas que se seguiram a essas efusivas, tem-se o Granodiorito Tipo Serra do Mel (Granodiorito Serra do Mel de Montalvão et alii, 1975) correspondente a etapas de intrusões ácidas a intermediárias, associadas à Formação Surumu, ocorrendo sob a forma de stocks circulares e elipsóides, ou tabulares, com idade isocrônica de $1700 \mathrm{~m}$.a. Associados à Formação Iricoumé, tem-se o Granito Tipo Mapuera (Granito Mapuera de Forman, 1969) com idades radiométricas entre 1800 a 1400 m.a. As fases subvulcânicas associadas à Formação Iriri receberam denominações diferentes de acordo com sua área de ocorrência. D.B. dos Santos et alii (1975) chamaram de Granito Maloquinha as intrusivas subvulcânicas comagmáticas à Formação Iriri na área da Folha SB.21 Tapajós, enquanto que G.H. Silva et alii (1974) chamaram de Granito Teles Pires aos da área da Folha SC.21 Juruena. O Granito Tipo Maloquinha apresenta idade isocrônica $\mathrm{Rb} / \mathrm{Sr}$ de 1650 m.a., e o Granito Tipo Teles Pires (Montalvão et alii. 1979a) $1548 \pm 28$ m.a. 
Um corpo circular com diâmetro aproximado de $2 \mathrm{~km}$ aparece na margem do rio Erepecuru, tendo recebido de Oliveira et alii (1975) a denominação de Sienito Erepecuru, colocado formando associação comagmática com as vulcânicas. Sua idade radiométrica obtida através do método $\mathrm{Rb} / \mathrm{Sr}$ em rocha total acusou $1804 \pm 69$ m.a. (Teixeira e Basei, 1975), sendo posicionado como uma das fases mais antigas do Grupo Uatumã, e colocado como anterior aos granitóides Tipo Serra do Mel, Mapuera, Maloquinha e Teles Pires. Por não ocorrerem nos domínios das vulcânicas do evento Uatumã, são aqui considerados isoladamente o Granodiorito Falsino (M.I.C. de Lima et alii, 1974) e o Sienito Mapari (Montalvão, 1976) correspondente as Alcalinas Mapari de M.I.C. de Lima et alii (op. cit.), sem serem posicionados como unidades litoestratigráficas deste grupo. $\mathrm{O}$ Granodiorito Falsino ocorre introduzido nos polimetamorfitos do Complexo Basal (Complexo Guianense) com formas circulares e elípticas em diversos locais da área da Folha NA/NB.22 Macapá. Suas idades trabalhadas em diagrama isocrônica $\mathrm{Rb} / \mathrm{Sr}$ de referência registraram um valor de 1746 m.a. O Sienito Maprai, é representado por corpos alcalinos de caráter hipoabissal a plutônico, principalmente sienitos e sodalita sienitos com idades convencionais $\mathrm{Rb} / \mathrm{Sr}$ de $1680 \pm 63$ m.a. e $1537 \pm 38$ m.a., considerados por Montalvão (op . cit.) como uma fase tardia do Grupo Uatumã ou reativação pós-plataformal.

Depois desse intenso vulcano-plutonismo, continuam os movimentos verticais menos intensos, porém registrados em toda a plataforma com formação de horsts e grabens. Nas depressões são depositadas espessas sequiências sedimentares, às vezes com vulcanismo associado. Dentre as unidades resultantes destes movimentos, pensa-se que o Grupo Roraima e a Formação Gorotire sejam as mais antigas. O Grupo Roraima deve sua denominação a Dalton (1912) que introduziu o nome Capas de Roraima, para a sequêência sedimentar exposta no Monte Roraima. Anderson e Dunn (1895) já haviam usado o termo Kaieteurian conglomerate para estes sedimentos na Guiana. Paiva (1939) foi o primeiro no Brasil a usar o termo Arenito Roraima, em vez do termo Kaieteurian usado pelos geólogos da Guiana. Martin-Kaye (1966) mostrou a prioridade do termo Roraima Séries usados em 1912 por Dalton (op. cit.) sobre o the Kaieteurian Series usado por Conally (1925). Barbosa e Ramos (1959) separaram a sequiência em duas formações: a inferior, Kaieteur, e a superior, Roraima. Os geólogos que se sucederam tanto no Brasil, como na Venezuela, Guiana e Suriname, não conseguiram separar a seqüência em formações, tendo abandonado o termo Formação Kaieteur. Sua colocação na categoria de grupo, deve-se a Reid (1972) que o dividiram em quatro formações: Formação Uairem; Formação Cuquenam; Formação Uaimapué e Formação Mataví, da base para o topo respectivamente. Bouman (1959) realizou, no Brasil, um trabalho específico sobre a "Formação" Roraima, que a divide em três membros denominados da base para o topo de Araí, Suapi e Quinô. Montalvão et alii (1975) aceitam o termo Grupo Roraima de Reid (op. cit.) e sugerem que os membros Araí, Suapi e Quinô de Bouman (op. cit.) sejam elevados a categoria de formações, em virtude da espessura desta unidade litoestratigráfica ser em média $2470 \mathrm{~m}$, como descrita por Bouman (op. cit.). O Grupo Roraima representa uma espessa sequiência sedimentar, composta de conglomerados, 'arenitos, siltitos, argilitos, folhelhos, cherts, jaspilitos, hornfels e camadas de tufos, metamorfisados devido a intrusões e falhamentos em bloco, e está destribuído na área em questão, principalmente no Território Federal de Roraima, daí sua denominação. Seu posicjonamento encontra-se baseado em datações de rochas básicas que o seccionam, as quais apresentam inúmeros resultados, e foram realizadas por diversos autores. Assim, Basei (1975) datou o hornfels em 1805 m.a.; McDougall, Compston e Hawkes (1963) e Snelling (1963) obtiveram valores entre 2000 e 1500 m.a.; McConell et alii (1964) obtiveram 1700 m.a. Já a Formação Gorotire, deve sua denominação a Barbosa et alii (1966) ao descreverem os sedimentos ocorrentes em restos isolados de ambos os lados do rio Xingu, do paralelo $6^{\circ}$ a $10^{\circ} \mathrm{S}$ e na bacia do rio Fresco. Ramos (1955) descreveu os sedimentos Gorotire, chamando atenção para a grande semelhança existente entre estes e a Formação Serra Grande, unidade basal da Sinéclise (Bacia) do Parnaíba, tendo inclusive, utilizado esta denominação no seu trabalho. Silva et alii (1974) chamam de Gorotire o conjunto das formações Gorotire e Cubencranquém (Barbosa et alii, $o p$. cit.), por não ter sido constatada qualquer discordância entre as duas unidades como relatado por aqueles autores. Compõe-se principalmente de arenitos e arcóseos, seguidos de conglomerado polimítico com seixos de vulcânicas, siltitos, argilitos, cherts, e estrutura de substituição em camadas cônicas e concêntricas tipo estromatólitos. Repousa sobre as vulcânicas do Grupo Uatumãa cujas idades já foram discutidas e Amaral (1974) refere-se a diques básicos datados em 1475 m.a., cortando esta unidade. CVRD/ /CMM (1972) considera os sedimentos da Serra dos Carajás como pertencentes a Formação Gorotire e cortada por Granitos Tipo Serra dos Carajás com idade de 1810 m.a. (K/Ar) e. 1710 m.a. (Rb/Sr).

Segue-se um magmatismo básico que ocorre na forma de sills e stocks denominado de Vulcanismo Básico Tipo Pedra Preta, (Diabásio Pedra Preta de Muniz et alii, 1974), distribuído principalmente nos domínios do Grupo Roraima, e como corpos isolados seccionando rochas do complexo basal, representados por gabro normal, olivina gabro, diabásios e noritos. O Vulcanismo Básico Tipo Pedra Preta foi primeiramente citado por Oliveira (1929) que relata espessa formação de arenitos, cortada por diques e massas de diabásio, no território do Rio Branco, atual Território 
Federal de Roraima. Guimarães (1930) descreve a petrografia e Paiva (1939) as condições de jazimento destes basitos. Barbosa e Ramos (1959) empregaram o termo Vulcanismo Roraima para este episódio de natureza básica. Vários autores estudaram esta unidade litoestratigráfica sempre empregando o termo Vulcanismo Roraima, entre eles Braun e Ramgrab (1972) e Bonfim et alii (1974), todos no Brasil, tendo sido estudado também por vários autores, tanto na Venezuela como nas Guianas. Muniz et alii (op. cit.), em virtude do termo Vulcanismo Roraima não ser coerente com o Código Americano de Nomenclatura Estratigráfica, denominam de Diabásio Pedra Preta, ao corpo intrusivo em forma de sill que aflora na localidade de Pedra Preta em Roraima. Ramgrab, Bonfim e Mandetta (1972) mapearam o Diabásio Pedra Preta, com a denominação de Vulcanismo Roraima e o subdividiram em Sill do Araí e Sill de Pedra Preta. Montalvão et alii (1975) inclui sob a denominação de Diabásio Pedra Preta, o corpo básico que ocorre em forma de dique na Serra do Araí, o sill do Monte Roraima e outros corpos básicos que assomam na região de Surucucu, todas no extremo Norte do Território Federal de Roraima. Na República da Guiana, o Vulcanismo Básico Tipo Pedra Preta é conhecido como Younger Basic Intrusive Group. Sua idade já foi discutida quando nos referimos ao Grupo Roraima. Enquanto isso, acredita-se que nesta mesma época, espesso pacote de sedimentos de mar raso com transição para o continente era depositado nos domínios do Graben ou Aulacógeno do Cachimbo, denominado de Grupo Beneficente. Tal unidade litoestratigráfica foi definida por Almeida e Nogueira Filho (1959) quando do reconhecimento do rio Aripuanã como constituída por litofácies inferior de natureza psamítica e outra mais elevada, heterogênea de natureza pelítica, depositado em ambiente epi-nerítico, marinho de águas rasas, e posteriormente metamorfisados na fácies xisto verde. Liberatore et alii (1972) referem-se ao Grupo Beneficente com os mesmos caracteres expostos e definidos por estes autores. Amaral (1974) correlaciona as rochas do Planalto do Cachimbo (Grupo Beneficente) às coberturas sedimentares das formações Gorotire, Riozinho do Anfrízio, Prosperança, Acari (?), Mutum-Paraná, Palmeiral, Parecis (em parte), Roraima e as da Serra do Tombador e Serra dos Caiabis. Santos et alii $(1974,1975)$ e G.H. Silva et alii (1974) tratam o Grupo Beneficente como relacionado a faixa Orogênica Aripuanã-Teles Pires, com posição estratigráfica abaixo do Grupo Uatumã. Issler $(1974,1977)$ aceitando o metamorfismo regional do Grupo Beneficente, sugere uma homologia e isocronia com o Grupo Grão-Pará (Cinturão Metamórfico Serra dos Carajás neste trabalho). Leal et alii (1978), baseados em Santos (1977), dão um novo enfoque ao Grupo Beneficente, negando seu metamorfismo regional e considerando as transformações dos sedimentos originais devidos a efeitos dinâmicos e/ou termais. Com isso, recolocam o Grupo Beneficente suprajacente a Formação Iriri, fazendo parte do Super Grupo Uatumã, que teria como unidade de topo a Formação Roosevelt, por eles definida. G.H. Silva et alii (no prelo) tratam este grupo como cobertura de plataforma isenta de metamorfismo regional, e estratigraficamente superposto às vulcânicas do Grupo Uatumã, e como tal é considerada neste trabalho. Distribui-se principalmente em áreas das Folhas SC.21 Juruena, SB.21 Tapajós, SB.20 Purus e SC.20 Porto Velho, sendo seus litotipos mais abundantes, arenitos ortoquartzíticos, arcósios, siltitos, folhelhos, calcários, chert, estromatólitos, e em menor quantidade quartzitos e quartzo-micaxistos restritos a zonas de falha, e raras ocorrências de fosfato e arenitos glauconíticos. Sua idade é relativa, pois as vulcânicas sotopostas apresentam isócrona de referência $\mathrm{Rb} / \mathrm{Sr}$ de $1596 \pm$ \pm 96 m.a., e no Domo de Sucunduri, localizado no canto noroeste da área da Folha SC.21 Juruena, rochas alcalinas que o seccionam apresentam idades convencionais de $1394 \pm 40$ m.a. (sienito) e 1160 m.a. (fonólito). Não se exclui a possibilidade desta unidade litoestratigráfica apresentar passagem lateral para a Formação Gorotire, sendo tão antiga quanto esta, fato já admitido por Pessoa et alii (1977). Acredita-se que ao mesmo tempo desta deposição ou anteriormente, em bacias tipo grabens, ou mesmo sobre outras áreas, depositavam-se os sedimentos com intercalações vuleânicas da Formação Mutum-Paraná. Esta formação foi definida por Lobato et alii (1967) a noroeste da Folha SC.20 Porto Velho onde está sua principal área de ocorrência. Pinto Filho et alii (1976) correlacionam a Formação Mutum-Paraná ao Grupo Beneficente. Leal et alii (1978) a englobaram no Grupo Beneficente e mapearam também como pertencente a este grupo os sedimentos que ocorrem no canto sudeste da área da Folha SC. 20 Porto Velho, tendo G.H. Silva et alii (no prelo) os estendido para a área da Folha SC.21 Juruena. Souza et alii (1975) admitem natureza vulcano-sedimentar em função dos tufitos intercalados na seqüência quartzito-filito. Montalvão et alii (1979c) acreditam que a Formação Mutum-Paraná e o Grupo Beneficente sejam provavelmente isócronas ou a primeira mais antiga, e a mapearam como unidades distintas em virtude das diferenças litológicas entre ambas. Neste trabalho concordamos com Montalvão et alii $(1979 \mathrm{c})$, colocando esta unidade litoestratigráfica na mesma posição estratigráfica do Grupo Beneficente, resguardando a possibilidade da Formação Mutum-Paraná ser mais antiga. É constituída de metarenitos feldspáticos, metarcóseos, conglomerados, grauvacas, arcóseos, rochas xistosas, filonitos, quartzitos e piroclastos, cujo metamorfismo é dínamo-cataclástico.

Após esta sedimentação, novamente ocorrem os eventos magmáticos caracterizados por intrusões de rochas graníticas e sieniticas, com idades entre 1600 e 1350 m.a., denominadas de Sienito Cachorro, Granito Surucucu e Granito Tiquié, todos ao norte da 
Sinéclise, não havendo dúvida que isto também ocor* reu a sul, sendo que ali tais corpos têm sido englobados em outras unidades litoestratigráficas, principalmente no Grupo Uatumã. O Sienito Cachorro (Oliveira $e t$ alii, 1975) assoma na margem esquerda do rio homônimo, com $25 \mathrm{~km}$ de comprimento por $6 \mathrm{~km}$ de largura, margeado pelo Granito Mapuera, apresentando idade convencional $\mathrm{Rb} / \mathrm{Sr}$ de $1460 \mathrm{~m}$.a. (Teixeira e Basei, 1975). O Granito Tipo Surucucu (Montalvão et alii, 1975) forma corpos subvulcânicos, anorogênicos, compostos de biotita ortoclásio granitos, quartzo-sienitos, alguns com textura rapakivi, intrusivos no Complexo Basal e no Grupo Roraima. São freqüentes nas proximidades da Serra do Surucucu a noroeste do Território Federal de Roraima, e datações radiométricas $\mathrm{Rb} / \mathrm{Sr}$ revelam valores entre 1500 e 1350 m.a. Já o Granito Tiquié (Pinheiro et alii, 1976) ocorre na parte ocidental da Amazônia Brasileira, Folha NA.19 Pico da Neblina, com forma circular e diâmetro aproximado de $2,5 \mathrm{~km}$ com idades convencionais em torno de 1500 m.a.

Continuando a tafrogenia, espessos pacotes sedimentares e vulcano-sedimentares são registrados, com a denominação de Formação Dardanelos (Grupo Caiabis), Formação Prosperança, Formação Prainha e Formação Cubencranquém. A Formação Dardanelos, foi definida por Almeida e Nogueira Filho (op. cit.) como uma seqüência de quartzitos tufáceos, mais ou menos conglomeráticos, conglomerados e tufos em parte ignimbríticos. Liberatore et alii (1972) correlacionam uma sequiência vulcano-sedimentar mapeada na área do Projeto Aripuanã-Sucunduri, com a Formação Dardanelos. G.H. Silva et alii (1974) chamam de Formação Prosperança à sequiência sedimentar exposta na Cáchoeira de Dardanelos, sem a intercalação vulcânica referida por Almeida e Nogueira Filho (op. cit.), e a caracterizam como uma cobertura de plataforma diretamente assentada sobre as vulcânicas do Grupo Uatumã. Almeida (1974) considera esta unidade litoestratigráfica uma seqüência vulcano-sedimentar, pertencente a época vulcânica representada pelo Grupo Uatumã. Padilha et alii (1974) chamam de Unidade PCII, aos chapadões de topo plano localizados entre os paralelos $11^{\circ} 00^{\prime}$ e $11^{\circ} 15^{\prime} \mathrm{S}$ e os meridianos $59^{\circ} 00^{\prime}$ e $60^{\circ} 00^{\prime} \mathrm{W}$ de Gr., e a correlacionam à Formação Dardanelos. G.H. Silva et alii (no prelo) correlacionam esta unidade litoestratigráfica à Formação Prainha de Almeida e Nogueira Filho (op, cit.). Estes mesmos autores mapearam nos domínios do Graben dos Caiabis uma intercalação de vulcânicas básicas nesta formação e criaram o Grupo Caiabis; considerando Dardanelos apenas os termos clásticos sendo as efusivas englobadas sob a denominação de Formação Arinos. Entre os autores que também referem-se a esta unidade litoestratigráfica ressaltam-se Amaral (1974), Basei (1977), P.F.C. Lima et alii (1975) e Leal et alii (1978). É constituida de conglomerados, arenitos e arcóseos com clay galls, ocorrentes em dis- cordância erosiva sobre os vulcanitos do Grupo Uatumã e polimetamorfitos do Complexo Basal (Complexo Xingu).

No norte da plataforma, ocorria a sedimentação representada pela Formação Prosperança, denominação devida a Paiva (1929), para rochas que ocorrem a $20 \mathrm{~km}$ da localidade Moura, no rio Negro. D.B. dos Santos et alii $(1974,1975)$, G. H. Silva et alii (1974), Leal et alii (1978), H.J.T. de Araújo et alii (1978) aceitam a correlação proposta por Caputo et alii (1971), desta formação com os sedimentos que ocorrem nos igarapés Preto, Ipiranga, Prainha e afluentes do rio Tapajós, e nos rios Capu-Capu, Jatapu, médio Tapajós, Abacaxis, Sucunduri e Negro. Geomineração (1972) designaram informalmente de Formação Sete Quedas aos sedimentos que ocorrem nas serras Sete Quedas, Sete de Setembro e Cansaço, localizadas a noroeste da Folha SA.21 Santarém em detrimento ao termo Formação Prosperança. J.F.V. de Araújo et alii (1976), tendo em vista a prioridade do termo Prosperança sobre Sete Quedas, consideram o primeiro para designar os sedimentos de cobertura para eles ocorrentes em ambos os flancos da Sinéclise (Bacia) do Amazonas. Entre os autores que estudaram esta formação destacam-se Swan (1958), chamando-a de Formação Jaú, Bouman (1959), J.O.S. Santos et alii (1974), Caputo e Sad (1974) e Lourenço et alii (1978). É composta de arenitos branco-amarelados, às vezes vermelhos, granulação média a grossá, friável e cimento silicoso, cortada por diques básicos datados em 1400 e 1100 m.a. Enquanto que a Formação Prainha, foi a designação proposta por Almeida e Nogueira Filho (op. cit.) para representar uma sequiência de siltitos e arenitos argilosos ocorrentes nas proximidades do povoado de Prainha, no leito do igarapé homônimo e nos barrancos do rio Aripuanã, a sudeste da área da Folha SB.20 Purus. Caputo et alii (op. cit.) correlacionaram à Formação Prosperança e deste modo foram seguidos por G.H. Silva et alii (1974), D.B. dos Santos et alii (1974), Leal et alii (1978) e H.J.T. de Araújo et alii (1978). Montalvão et alii $(1979 \mathrm{c})$, achando precipitada tal correlação preferem manter a denominação Prainha para as coberturas de plataforma anteriormente mapeadas como Prosperança, nas áreas das Folhas SB.21 Tapajós, SC.20 Porto Velho e SB.20 Purus, o que é aceito neste trabalho. E constituída de arenitos arcoseanos, intercalando argilitos e siltitos vermelhos, característicos de ambiente continental, sendo uma unidade de cobertura que transgride sobre o Complexo Xingu, Grupo Beneficente e Grupo Uatumã, bem representada no canto sudeste da área da Folha SB.20 Purus, no ramal que liga a rodovia Transamazônica ao povoado de Prainha, sua localidade tipo.

A Formação Cubencranquém, foi definida por Barbosa et alii (1966), com seção e localidade tipo na Serra de Cubencranquém na porção NNO da área da Folha SC.22 Tocantins. Está representada por rochas 
predominantemente avermelhadas em parte rosadas, granulação mormente finas, siltitos e arenitos finos. Sua colocação neste trabalho é feita com uma certa dúvida, haja visto que em trabalhos anteriores observa-se que há uma certa polêmica com relação a sua diferenciação da Formação Gorotire. G.G. da Silva et alii (op. cit.) mapearam como Gorotire o conjunto das duas formações, o mesmo acontecendo com DNPM (1975) que as considera como indiferenciadas, não excluindo a possibilidade de caracterizá-las como unidade distintas. Perfis realizados nas seções e localidades tipo destas duas unidades litoestratigráficas, evidenciaram diferentes tipos litológicos que tanto podem representar unidades distintas como variações de fácies entre as mesmas. Pessoa et alii (1977) subdividiram a Formação Cubencranquém, na área do Projeto Jamanxim, em Membro Inferior, formado de conglomerados, brechas e arcóseos, com siltitos e argilitos associados; Membro Médio, constituído por tufos cineríticos; e Membro Superior, caracterizado pela predominância de arcóseo, com siltitos e argilitos intercalados. Para esses autores; a Formação Cubencranquém corresponde às formações Riozinho do Anfrízio (SUDAM, 1972), Triunfo (G.G. da Silva et alii, op. cit.) e Prosperança, de D.B. dos Santos et alii $(1974,1975)$; neste trabalho corresponde provavelmente às formações Prainha e Dardanelos.

Durante essa tafrogenia, intenso magmatismo básico, intermediário e ácido ocorreu, sendo os representantes básicos denominados de Vulcanismo Básico Tipo Arinos, Vulcanismo Básico Tipo Ciriquiqui (variedade ultrabásica) e Vulcanismo Básico Tipo Suretama. Teixeira (1978), com base em determinações radiométricas $\mathrm{K} / \mathrm{Ar}$ e $\mathrm{Rb} / \mathrm{Sr}$, define quatro conjuntos de rochas básicas pré-cambrianas $(2000-1550$ m.a., $1500-1300$ m.a., 1250 - 1050 m.a., $1050-650$ m.a.). $\mathrm{Na}$ parte sul da plataforma, considerada como Craton do Guaporé, destaca os derrames na Serra dos Pacaás Novos e a intrusiva alcalina do Domo de Sucunduri. Santos e Oliveira (1978) posicionam o magmatismo básico-alcalino anorogênico da Plataforma Amazônıca no Proterozóico Superior, denominando-o de Evento Magmático Cachoeira Seca com idade entre 1000 e 1060 m.a. O Vulcanismo Básico Tipo Arinos, corresponde à Formação Arinos, de G.H. Silva et alii (no prelo), que mostra, no extremo oeste da Serra dos Caiabis, efusões básicas constituindo pelo menos dois niveis de basalto (toleíticos, alcalinas e calco-alcalinos), intercalados nos sedimentos denominados de Formação Dardanelos. Sua área de distribuição foi delimitada através de imagem de radar, daí a necessidade de novos trabalhos de campo para confirmar ou não esta distribuição conforme o pensamento de G.H. Silva et alii (op. cit.). Tassinari, Teixeira e Siga Jr. (1978, apud G.H. Silva et alii, no prelo) realizaram datações K/Ar nessas rochas para o Projeto RADAMBRASIL e apresentaram valores de 1400 m.a. em uma amostra de efusão inferior e outra de 1200 m.a. para a efusão superior. Com relação ao Vulcanismo Básico Tipo Ciriquiqui, denominado de Básicas e Ultrabásicas do Ciriquiqui por Leal et alii (1978), e correspondente a Associação Básico-Anortosítica de Dreher, Araújo e Abreu (1976), encontram-se bem expostas nas margens e mesopotâmia Ciriquiqui e Curuquetê rios que drenam o canto noroeste da área da Folha SC.20 Porto Velho. Dentre suas variedades petrográficas incluem-se anortositos, gabros, diabásios, granófiros, quartzo-monzonitos, noritos, piroxenitos, serpentinitos e andesitos, cujas idades radiométricas $\mathrm{K} / \mathrm{Ar}$ revelaram valores de $1372 \pm 21$ e $1366 \pm 18$ m.a. O Vulcanismo Básico Tipo Suretama (Gabro Suretama de Montalvão, 1974) é constituído de diques, stocks e sills (?) orientados nas direções NNW, N, NW e NE; petrograficamente classificados como gabros normais, olivina gabros, olivina diabásios, noritos e hiperstênio diabásios. Estas rochas foram primeiramente estudadas por Geomineração (1972) no morro do Suretama, e apresentam idades (K/Ar) em plagioclásio de $1420 \pm 32$ m.a. a $1164 \pm 62$ m.a.

No que concerne aos termos ácidos e intermediários temporalmente correlatos àquele vulcanismo básico, foram denominados Granito Tipo Serra da Providência, Granito Tipo Velho Guilherme e Sienito Serra Acari, distribuidas em toda a Plataforma Amazônica na área considerada. O Granito Tipo Serra da Providência (Montalvão et alii, 1979a) foi definido por Leal et alii (1976) com a denominação de Granito Serra da Providência representando uma intrusão granítica de forma alongada, com dimensão batolítica, que afeta os arenitos mapeados por esses autores como Grupo Beneficente, tendo G.H. Silva et alii'(no prelo) os estendido para a área da Folha SC.21 Juruena. Vários autores estudaram estas intrusivas sem lhes atribuir uma designação formal, destacando-se entre eles, Lobato et alii (1967), que descrevem a existência de corpos intrusivos de dimensões batolíticas na região da Serra da Providência, acidente geográfico que separa o Território Federal de Rondônia do Estado de Mato Grosso. Leal et alii (1974) que correlacionam aos Younger Granites da Nigéria (Kloosterman, 1967); Padilha et alii (1974) e Dall'agnol et alii (1975). Petrograficamente apresentam variedades pórfiras, viborgitos, piterlitos, equigranulares, ocorrendo jazimento subvulcânico, estando suas idades radiométricas $\mathrm{Rb} / \mathrm{Sr}$, distribuídas entre $1414 \mathrm{~m}$. a. e $1058 \mathrm{~m}$.a. Além deste aparece o Granito Tipo Velho Guilherme (Granito Velho Guilherme, G.G. da Silva et alii, op. cit.) ocorrenté na área da Folha SB.22 Araguaia, representando mais de duas dezenas de corpos graníticos circulares, com idade radiométrica convencional $\mathrm{Rb} / \mathrm{Sr}$ de $1384 \pm$ \pm 59 m.a. (Basei, 1973) e o Sienito Serra Acari (Fernandes e Morais, 1975) ocorrente na Folha SA.21 Santarém, colocado com reservas na mesma posição estratigráfica dos granitos Tipo Velho Guilherme e Serra da Providência.

Após isso, voltam a ocorrer episódios magmáticos 
intrusivos e vulcânicos, representados principalmente por sienitos e monzonitos que ocorrem a sul da sinéclise (Folha SC.20 Porto Velho e SC.21 Juruena) denominados de Sienito Canamã, Sienito Teotônio e Sienito Guariba. Montalvão et alii (1979a), baseados principalmente em G. H. Silva et alii (no prelo) e Leal et alii (1978), realizam um estudo completo sobre os granitóides e rochas afins mapeadas em áreas das Folhas SC.20 Porto.Velho, SB.20 Purus e SC.21 Juruena, abordando aspectos petrográficos, petroquímicos, estruturais e metalogenéticos, do Sienito $\mathrm{Ca}$ namã, Sienito Teotônio e Sienito Guariba, bem como Granitos Tipo Teles Pires, Rondonianos e Serra da Providência. O Sienito Canamã foi primeiramente estudado por Silva e Issler (1974, apud G.H. Silva et alii, no prelo), sendo o representante de uma estrutura circular que sobressai na topografia, situada a nordeste de Dardanelos, Folha SC.21 Juruena, ressaltando sua superioridade dimensional $(21 \mathrm{~km}-$ - $12 \mathrm{~km})$ ao complexo anular de Glitrevan $(16 \mathrm{~km}-$ - $10 \mathrm{~km}$ ) na Noruega e ao maciço de Nunarssuit $(20 \mathrm{~km}-12 \mathrm{~km})$, na Groenlândia, os maiores do mundo. G.H. Silva et alii (1974) o consideram como fase tardia do Grupo Uatumã. G.H. Silva et alii (no prelo) considerando sua distribuição, em outros locais da área da Folha SC.21 Juruena, e sua variedade litológica, denominam de Alcalinas Canamã, e as colocam como pertencente ao Grupo Caiabis. Estão representados por uma ampla variação petrográfica, e apresentam idade isocrônica $\mathrm{Rb} / \mathrm{Sr}$ verdadeira de $1175 \pm 30$ m.a. Quanto ao Sienito Teotônio, foi primeiro descrito por Evans (1950, apud LASA, 1964) que se refere ao sienito cortado por veios de quartzo no leito do rio Madeira. Leal et alii (1978) deram o nome a estas rochas e a delimitam em imagem de radar, como uma estrutura perfeitamente circular no leito do rio Madeira à jusante de Porto Velho. Petrograficamente é constituído de granitos, monzonitos e sienitos, cujas determinações radiométricas $\mathrm{Rb} / \mathrm{Sr}$ acusaram, $1201 \pm 104$ m.a., $1249 \pm 60$ m.a. e $950 \pm 31$ m.a. O Sienito Guiariba (Montalvão et alii, 1979a) corresponde às Alcalinas Guariba de Leal et alii (op. cit.), e representa alguns corpos intrusivos formando um conjunto de morros alinhados, situados a $100 \mathrm{~km}$ à montante da $\mathrm{Foz}$ do rio Guariba, nordeste da Folha SC.20 Porto Velho. Petrograficamente é composto de ortoclásio pertítico, oligoclásio, hastingsita, sendo este o máfico principal, com idade radiométrica $\mathrm{Rb} / \mathrm{Sr}$ de 1100 m.a. (G.H. Silva, inf. verbal).

Após a introdução destes corpos alcalinos, segue-se uma fase eminentemente ácida representada pelos Granitos Tipo Rondonianos e vulcânicas a eles associados denominadas de Efusivas Ácidas do Caripunas. Os Granitos Tipo Rondonianos (Montalvão et alii, 1979a, correspondente aos Granitos Rondonianos de Leal et alii, op. cit.), ocorrem principalmente nos domínios das áreas das Folhas SC.20 Porto Velho e
SB.20 Purus, e muito importantes economicamente, uma vez que são mineralizados a cassiterita. Foram estudados por Kloosterman $(1966,1967,1968)$ que os denominou de Younger Granites of Rondonia estabelecendo uma correlação com os Younger Granites of Nigeria, vindo a separar 21 corpos circunscritos, sendo que pelo menos a metade desses são mineralizados a cassiterita e topázio. Verschure e Bon (1972) concordam com esta correlação. Souza et alii (1975) e Pinto Filho et alii (1976) cognominaram-nos de Granitos Anorogênicos, sendo que os primeiros citam a presença de textura rapakivi nos granitos do complexo de São Lourenço (Folha SC.20 Porto Velho). Petrograficamente ocorre em uma ampla variação de granitos com ortoclásio e microclínio, albitizados e greisenizados, contendo topázio, fluorita e cassiterita como acessórios, sendo as variedades rapakivi e porfiritica comuns. Diversos autores estudaram estes granitos, advindo daí, inúmeras datações radiométricas, como por exemplo, $977 \pm 20$ m.a. (Priem et alii, 1971) e $1152 \pm 38$ m.a. (Teixeira e Tassinari, 1977). Esta intensa atividade magmática geradora dos granitos estaníferos na área da Folha SC.20 Porto Velho, entre aproximadamente 1100 e $980 \mathrm{~m} . \mathrm{a}$. foi denominada de Evento Ígneo Rondoniense por Amaral (op. cit.). Os Granitos Tipo Rondonianos se encontram associados a riolitos, riodacitos, metadacitos e meta-andesitos, que receberam de Leal et alii (op. cit.) a denominação de Efusivas Ácidas do Caripunas com isócrona $\mathrm{Rb} / \mathrm{Sr}$ de referência de $1040 \pm 44$ m.a:, cuja maior área de exposição encontra-se no canto noroeste da Folha SC.20 Porto Velho, em domínios do rio homônimo. Referências sobre estas efusivas são observadas em Kloosterman (1966), Lobato et alii (1967), Priem et alii (1971) e Souza et alii (1975), que sempre as associam aos corpos intrusivos dos Granitos Tipo Rondonianos. Na porção mais setentrional da Folha NA.21 Tumucumaque, a norte da plataforma na área considerada, divisa com a república da Guiana, aparece um corpo com aproximadamente $10 \mathrm{~km}$ de diâmetro em território brasileiro, que recebeu de Montalvão e Abreu (1975) o nome de Sienito Mutum. Trata-se de um nefelina sienito com bastante carbonato no espaço intergranular, cuja idade convencional $\mathrm{K} / \mathrm{Ar}$ acusou $1026 \pm 28 \mathrm{~m}$.a., tendo Montalvão (1976) o correlacionado ao Episódio Nickeriano (Priem et alii, 1971). Nos tratos da Folha SC.20 Porto Velho, durante este vulcanoplutonismo, eram depositados sedimentos, associados a um vulcanismo básico (basaltos), formando o Grupo Guajará Mirim (Leal et alii, op. cit.), datado em 1000 m.a., constituído pela Formação Nova Floresta e Pacaás Novos, onde o pacote de arcóseos e conglomerados polimíticos desta última recobrem os basaltos com restritas intercalações de arcóseos da Formação Nova Floresta, e edificam as Serras dos Pacaás Novos e Uopione.

Acredita-se que o último movimento do Proterozóico Superior com sedimentação, tem como exemplo 
o graben de Pimenta Bueno, que assistiu a deposição da Formação Pimenta Bueno. Tal formação deve sua caracterização como unidade litoestratigráfica formal a Leal et atii (1978), tendo primeiro sido estudada por Oliveira (1915/1918), e posteriormente por Dequech (1943), que chamou os pelitos de folhelhos do Apidiá; Lobato et alii (1967) que a incluem na Formação Parecis (Oliveira, op. cit.); e Pinto Filho et alii (1976) que a chamaram de Unidade Permo Carbonífera I (PCI), incluindo, nesta, depósitos glaciais. Compreende ruditos, arenitos e lutitos, subordinadamente carbonatos e lentes de carvão, confinados a um sulco tectônico denominado de Graben de Pimenta Bueno, com presença marcante a sul da área da Folha SC. 20 Porto Velho.

No fím do Proterozóico Superior ou começo do Paleozóico houve edificação da Sinéclise do Amazonas, com espessa sedimentação "inicial" constituindo o Grupo Urupadi (D.B. dos Santos et alii, 1975) subdividido nas formações Trombetas, Maecuru e Ererê. A Formação Trombetas (Derby, 1898) de idade Ordoviciana Superior a Siluriana Superior é a unidade basal da Sinéclise (Bacia) do Amazonas, e compõe-se de arenitos, siltitos, folhelhos, lentes de chert, com um predomínio dos primeiros sobre os demais, e subdividida nos membros Autás Mirim, Nhamundá, Pitinga e Manacapuru (Caputo et alii, 1971). A Formação Maecuru (Derby, 1877) de idade Eodevoniana, compõe-se de arenitos, argilitos e folhelhos, enquanto que a Formação Ererê (Hartt, 1896) é constituída de siltitos com intercalações de arenitos na base, seguida de arenitos passando a siltitos para o topo, e colocada no Mesodevoniano (Caputo et alii, op. cit.). No Paleozóico Inferior somente tem-se registro de vulcanismo básico no Devoniano Superior e restrito, denominado de Diabásio Taiano (Formação Taiano de Amaral, 1974) (360 m.a.), e localizado na Folha NA/NB.20 Boa Vista/Roraima, representando uma intrusão em forma de dique com mais de $100 \mathrm{~km}$ de extensão, e em vista disso é provável que entre as intrusões existentes nos domínios da bacia em sub. superficie algumas pertençam ao Paleozóico Inferior a Médio. A sedimentação na Sinéclise prossegue no Eocarbonífero com a deposição dos pelitos da Formação Curuá (Derby, 1877) subdividida nos membros Barreirinha, Panacu, Curiri e Oriximiná. Durante o Carbonifero houve a deposição do Grupo Tapajós, (D.B..dos Santos et alii, 1975), constituído pelas formações Monte Alegre, Itaituba e Nova Olinda, distribuído segundo uma faixa alongada nas bordas sui e norte da Sinéclise do Amazonas, guardando a mesma orientação da Formação Curuá e Grupo Urupadi. A Formação Monte Alegre (Freydank, 1957) é constituida por arenitos finos a médios, conglomeráticos na base, passando gradualmente a finos no topo com estratificação cruzada, ocorrendo subordinadamente folhelhos. A Formação Itaituba (Hartt, 1896) compõe-se predominantemente de calcários fossilíferos, folhelhos, siltitos, arenitos finos, com evaporitos associados aos dois primeiros. A Formação Nova Olinda (Kristler, 1954) constitui-se principalmente de evaporitos (anidrita), com camadas e lentes interdigitadas de folhelhos, siltitos, calcários e arenitos, tendo idade compreendida no intervalo que vai do Neocarbonífero até o Mesopermiano (Daemon e Contreiras, 1971). Enquanto isso se iniciava a sedimentação na Bacia do Acre com a deposição de quartzitos, arenitos quartzíticos, metassiltitos e camadas de chert, da Formação Formosa (Leite, 1958) metamorfisada por intrusão de rochas sieníticas. Na porção meridional da área, houve uma ampla deposição com características eólicas, fluviais, flúvio lacustre e aspecto tabular, tipicamente de cobertura correspondente ao Arenito da Fazenda Casa Branca (Leal et alii, 1978), composta de arenitos, conglomerados, siltitos, argilitos e lamitos, recoberto em sua porção oriental pelas coberturas sedimentares cenozóicas (Formação Araguaia), aparecendo já nos domínios da área da Folha SC.22 Tocantins, onde é considerada por Barbosa et alii (1966) e DNPM (1975) como Formação Aquidauana.

No fim do Paleozóico (Permiano) e no Triássico, Jurássico e início do Cretáceo, desencadeou tanto nos domínios da sinéclise como nos domínios cristalinos da Plataforma Amazônica, intrusões em formas principalmente de diques e derrames (Formação Apoteri) denominados de Diabásio Cassiporé e Diabásio Penatecaua. O Diabásio Penatecaua deve sua denominação à Issler et alii (1974), para designar as rochas básicas introduzidas durante o intervalo Jurássico-Cretáceo em sedimentos da Sinéclise do Amazonas. O Diabásio Cassiporé foi definido por M.I.C. de Lima et alii (1974) e designa um enxame de possantes diques aproximadamente paralelos de magma básico de caráter toleitico, ocorrente principalmente na parte norte e nordeste da Folha NA/NB.22 Macapá, produto de estágio de reativação a que a plataforma Amazônica foi submetida. Esta manifestação magmática recebeu a denominação de Episódio Cassiporé, datado em 250 - 180 m.a. (M.I.C. de Lima et alii, op. cit.). Acrescenta-se a estes o Diabásio Cururu (G. H. Silva et alii, 1974), ocorrente somente nos domínios da plataforma, representando intrusões em forma de diques quilométricos, bem expostos em áreas das Folhas SB.21 Tapajós e SC.21 Juruena. Ainda no Mesozóico (Jurássico-Cretáceo) houve a edificação do Graben do Takutu com efusão básica (basalto) pertencente à Formação Apoteri e deposição de sedimentos clásticos continentais da Formação Takutu. Os basaltos da Formação Apoteri (Berrangé, 1967), encontram-se expostos no canto nordeste da área da Folha NA.20 Boa Vista, proximidades da cidade de Boa. Vista e a noroeste da área da Folha NA.21 Tumucumaque, divisa com a República da Guiana, enquanto que os arenitos, siltitos e folhelhos, horizontais a subhorizontais da Formação Takutu (Barrington Brown, 1875, apud Carneiro et alii, 1968) estão bem preservados no Graben do Takutu. 
No Cretáceo Médio ocorreu a intrusão do Sienito Catrimani, com idade $\mathrm{Rb} / \mathrm{Sr}$ de 100 m.a. e provavelmente a intrusão do Carbonatito Seis Lagos. O Sienito Catrimani (Montalvão et alii, 1975) representa corpos intrusivos anorogênicos do tipo sodalita, nefelina sienito (Litchfieldito) cortado por diques de fonólitos, ocorrente na porção centro-sudeste da área da Folha NA.20 Boa Vista, primeiramente estudados por Santos e Salas (1974). O Carbonatito Seis Lagos (Pinheiro et alii, 1977), é uma intrusiva carbonatítica brechada com estrutura de fluxo e pisolítica, ocorrente no morro dos Seis Lagos, centro-sudeste da área da Folha NA.19 Pico da Neblina. Ligada provavelmente ao mesmo evento que assistiu a introdução do Sienito Catrimani e Carbonatito Seis Lagos, está a alcalina da Serra do Maecuru, que recebeu de Montalvão (1976) a denominação de Alcalinas do Maecuru, localizada no canto NE da Folha SA.21 Santarém, representando um corpo grosseiramente circular com diâmetro de $10 \mathrm{~km}$, introduzido nos polimetamorfitos do Complexo Basal.

Enquanto isto, prosseguia a sedimentação na Bacia do Acre, com a deposição das formações Moa, Rio Azul e Divisor (Moura e Wanderley, 1938), aqui englobadas sob a denominação de Unidades Cretácicas da Bacia do Acre.

Segue-se a sedimentação de ampla área, no Cenozóico e quiçá Cretáceo Superior do Grupo Barreiras (?) ou Alter do Chão, formação Solimões, Ramon e Araguaia e os sedimentos quaternários mais novos restritos principalmente as aluviões dos rios.

TECTÔNICA Com ajuda das interpretações de imagens de radar e dados de campo, observou-se que a Plataforma Amazônica foi palco, além das orogenias, também de diatrofismos marcantes representados pelos movimentos epirogenéticos, sendo eles responsáveis por falhamentos em blocos, com longo tempo de atuação, ligados aos processos de reativação, associados, quase sempre, a atividades magmáticas e sedimentação.

O "Complexo Basal" (Complexo Guianense e Complexo Xingu) é constituído de rochas crustais arrasadas, devendo-se aos processos de anatexia e reomorfismo em rochas plásticas, à imposição de estruturas anelares, fusiformes, dômicas, dobradas, sendo estas difusas e irregulares. Os bandeamentos dos gnaisses e migmatitos juntamente com as outras estruturas de deformação (eixos de dobras, lineações, xistosidades) apresentam direções N-S, NW-SE, NE-SW, WNW-ESE, NNW-SSE, ENE-WSW e outras variações.

Os metamorfitos que compõe os cinturões metamórficos descritos apresentam as mais diversas direções de foliações. Assim, observa-se no Cinturão Metamórfico Serra dos Carajás direções segundo NW-SE, WNW-ESE, E-W e ENE-WSW; no cinturão metamórfico Vila Nova-Jari estas pronunciam-se se- gundo NW-SE, WNW-ESE, NNW-SSE, E-W, ENE-WSW e NNE-SSW; no Cinturão Metamórfico Cauarane (?) são notáveis os xistos com direções de foliações principais segundo NNW-SSE e NW-SE; e no tocante ao Cinturão Metamórfico Tunui, as direções de foliações mais pronunciadas estão segundo NW-SE e NNW-SSE.

As estruturas dos "Cinturões Metamórficos" possuem xistosidade, clivagem ardosiana e clivagem de fratura, isto é, tipos de foliação conspícuas que dificilmente ocorrem em rochas do "Complexo Basal", caracterizado por espécimes de mais alto' grau metamórfico, onde são comuns o bandeamento e, subordinadamente, a xistosidade.

As coberturas de plataforma, assim como o vulcanismo Uatumã e outros, apresentam suas camadas horizontais a subhorizontais e, quando dobradas, têm estilo descontínuo com a formação de domos, braquianticlinais, braquissinclinais, sinclinais e anticlinais amplas com mergulhos suaves, e monoclinais, devido a movimentos verticais de blocos, intrusões ígneas e fluxo de material mais plástico entre material menos plástico.

As unidades paleozóicas da Sinéclise ou Graben do Amazonas apresentam-se, de modo geral, horizontais a subhorizontais e quando dobradas também obedecem ao mesmo estilo de dobramento.

Das orogenias e movimentos epirogênicos, qué atuaram na Plataforma Amazônica, resultaram lineamentos, horsts, grabens, aulacógenos e sinéclise. Os lineamentos são ressaltados pelos cinturões metamórficos, dobrados, alinhados, com estruturas foliadas marcantes, bem mais expressivas nos xistos do que nos anatexitos e migmatitos do "Complexo Basal". Outros lineamentos são caracterizados por sistemas de falhamentos impostos nas rochas gnáissico-migmatíticas, assim como nos enxames de diques orientados ou mesmo intrusões ígneas circulares, que constituem feições morfotectônicas de extensões apreciáveis nas imagens de radar onde o ressalte topográfico é notável. Diversos lineamentos foram descritos por: Montalvão et alii (1975), D.B. dos Santos et alii (1975), M.I.C. de Lima et alii (1974), G.G. da Silva et alii (1974), G.H. Silva et alii (no prelo) e Leal et alii (1978), entre outros que trabalharam na região em apreço. Observa-se, também, às vezes mais de um nome para o mesmo lineamento.

CONCLUSÃO Com base nos trabalhos existentes na Amazônia, e principalmente nos resultados obtidos pelo Projeto RADAMBRASIL, chega-se as seguintes conclusões:

a) A existência provável de uma crosta de composição granítica - granodiorítica - tonalítica, que constitui o "Complexo Basal" (Complexos Xingu e Guianense), formada por rochas com idades do Pre- 
cambriano Inferior a Médio, retrabalhada (rejuvenescida) durante o Precambriano Superior. Esta crosta que faz parte da Plataforma Amazônica apresenta uma composição siálica bem antiga, ocorrendo núcleos de composições mais básicas, formados principalmente por granulitos, quartzo-diorito e anfibolitos;

b) Após sua formação, esta crosta sofreu fraturamentos com formações de grabens, causados por tensões ou mesmo por afundamento de blocos, devido a movimento vertical, associado a rift falhamentos.;

c) Estes grabens caracterizam o receptáculo de sequiências vulcano-sedimentares e sedimentares. Suas fraturas fundamentais, às vezes atingiram o manto, evidenciando então a presença de magmatismo básico-ultrabásico, associado à sedimentação de mar raso com presença de formações ferríferas, denunciando características de bacias intracratônicas (intraplataformais). Porém não excluímos que os magmatitos básicos-ultrabásicos representem "restos" de uma crosta de composição oceânica, constituindo mega-enclaves;

d) Depois dessa fase de sedimentação, estabeleceram-se as transformações dessas unidades, com dobramento, metamorfismo e granitização. É provável que o Cinturão Metamórfico Vila Nova-Jari e "Cinturão Metamórfico Cauarane?" tenham sofrido granitizações. O mesmo parece não ter acontecido com os Cinturões Metamórficos do Tunui e Serra dos Carajás. Essas transformações foram causadas por forças compressionais e/ou crumpling. Estes cinturões foram formados provavelmente durante o Pré-Cambriano Médio (2200 m.a. - 1900 m.a.). Por falta de melhores estudos geológicos e geocronológicos, evitamos afirmar as idades desses eventos tectônicos. Não se exclui a possibilidade de idade arqueana para o Cinturão Metamórfico Serra dos Carajás, uma vez que as rochas granitóides que assomam nas proximidades da Serra do Inajá apresentam isócrona $\mathrm{Rb} / \mathrm{Sr}$ de 2750 m.a. Em último caso, estas poderiam ter sido formadas por fusão parcial de rochas na interface do craton com o cinturão, no momento do afundamento das rochas crustais por peso das rochas mais densas pertencentes ao cinturão, conforme modelo de MacGregor (1951) e Glikson (1972). O mesmo raciocínio poderia ser válido para o "Cinturão Metamórfico Vila Nova-Jari";

e) A partir de 1900/1800 m.a. não temos registros de formações de outros Cinturões Metamórficos. Acredita-se que, quando findava a orogênese, prevalecia o movimento vertical de blocos com formações de grabens ou aulacógenos e pilares. Começa então o vulcano-plutonismo denominado de Grupo Uatumã com intercalações de sedimentos em bacias isoladas. Registram-se também intrusões e, bacia ou bacias de sedimentação isoladas antes da formação do intenso vulcano-plutonismo. Acredita-se em um intervalo mínimo de 300 a 350 milhões de anos para o episódio mais marcante da plataforma, representado pelo Grupo Uatumã ; f) A movimentação de bloco com sedimentação e intenso vulcano-plutonismo, que se acredita ter iniciado por volta de $2000 \mathrm{~m}$.a., continua até o Mesozóico, sendo porém mais atuante aurante o Pré-cambriano;

g) Admite-se que durante o Pré-cambriano 'Superior ou Paleozóico Inferior foi edificada a Sinéclise ou Graben do Amazonas, e nela depositado espesso pacote de sedimentos predominantemente Paleozói$\cos$;

h) Durante o Paleozóico Inferior e Médio são raros os registros de atividades magmáticas, ocorrendo na Folha NA/NB.20 esparsos diques básicos, com idade de $360 \mathrm{~m}$.a. Porém, no fím do Paleozóico (Permiano) e durante o Mesozóico (Triássico-JurássicoCretáceo) intenso magmatismo básico ocorreu em toda a área da Plataforma Amazônica, dentro da bacia e fora da mesma, representando principalmente por intrusões de diques e derrames de lavas. Durante o Mesozóico, a sedimentação é representada principalmente no Graben do Takutu e nos domínios da Bacia do Acre;

i) Acusa-se que, no fim do Mesozóico (Cretáceo Superior) e durante o Cenozóico, cessaram as atividades ígneas, e a tectônica de bloco não é tão marcante. Imensas áreas são movimentadas de maneira lenta com sedimentação de material clástico detrítico-carbonático, de ambiente continental e localmente marinho, depositadas em todo o domínio da Bacia do Amazonas (Baixo, Médio e Alto) e Bacia do Acre e transgredindo sobre as zonas cristalinas estáveis, capeando unidades mais antigas, inclusive com deposição na zona pericratônica entre o Cinturão Andino e borda do craton;

j) Do exposto no trabalho, e observando-se a coluna e mapa geológico, pode-se concluir que se tem, a grosso modo, uma equivalência de eventos geológicos nas porções cristalinas situadas a norte e sul da Sinéclise do Amazonas, havendo, portanto, a necessidade de uniformizar esta unidade geotectônica como um todo;

k) As bacias da Plataforma Amazônica são principalmente do tipo grabens, algumas denominadas de aulacógeno e rift valley. Estas bacias foram formadas por falhamentos crustais que muitas vezes atingem o sima e/ou o manto, originando intrusões de rochas ígneas básicas e ultrabásicas. As bacias do tipo pericratônica e sinéclise são menos comuns. Acredita-se que a Bacia do Amazonas é uma sinéclise (Issiler, 1974), e como pericratônica tem-se a bacia entre a margem ocidental da plataforma e o cinturão Andino, ocupando parte da Bacia do Acre e Alto Amazonas (?). Muratov (1972) acredita que estes dois tipos de baciast estão ligados à fase de processo de compactação sub-crustal;

1) Como já citamos no início do trabalho, por que não enquadramos os cinturões metamórficos dentro do modelo clássico de geossinclinais. A evolução dessas para o estágio de Plataforma é imprecisa, uma vez que 
os estágios de transições, estabilizações e reativações pós-plataformais, às vezes se confundem;

m) Quanto a Serra do Inajá, além da idade Arqueana Superior dos granitóides das áreas vizinhas, foram feitas várias análises químicas (elementos maiores e elementos traços, estes últimos por espectografia óptica de emissão) que estão sendo colocados em gráficos petroquímicos, com o fito de comparações com komatiitos de outras regiões. Durante o reconhecimento geológico realizado neste cinturão não foram encontradas estruturas spinifex e poliedral, cracterísticas daquelas rochas. Alerta-se também para trabalho orientado nos meta-basitos e meta-ultrabásicas do Cinturão Metamórfico Vila Nova-Jari, principalmente no que concerne as estruturas como pillowed, spinifex e poliedral e estudo petroquímico;

n) O limite da Plataforma (Craton) Amazônica, principalmente nas porções sul e sudeste, através do Cinturão Metamórfico Paraguai-Cuiabá e parte do Cinturão Metamórfico Tocantins-Araguaia, ambos constituindo o "Geossinclínio Paraguai-Araguaia" de Almeida (1967), é ainda bastante impreciso, haja visto a falta de dados concretos entre a relação destes cinturões e o Cinturão Metamórfico Araxá. Entre este cinturão e aqueles ocorre uma lasca do "Complexo Basal", que compreende o Maciço Central Goiano (Almeida, 1967) que dificulta a definição dos cinturões como posições inter ou intraplataformal. Sendo portanto dificil separar nesta região a Plataforma Amazônica da Plataforma do São Francisco;

o) Aconselha-se maior cautela no emprego dos nomes para as unidades litoestratigráficas existentes na Plataforma Amazônica. Sabe-se que, atualmente, com o uso de imagens de radar e fotografias conven- cionais, podemos verificar, em parte, a continuidade das formações geológicas, não sendo necessário o uso de vários nomes para a mesma unidade. Neste trabalho se procura sintetizar a geologia da Amazônia e empregar, na medida do possível, o Código de.Nomenclatura Estratigráfica. Porém sabe-se que é muito dificil, devido a falta de maior conhecimento da geologia e a grande quantidade de nomes propostos, e destarte procura-se enquadrar certos eventos na categoria informal. Como exemplo, ao conjunto de granitos com características petrográficas pós-cinemáticas, às vezes com idades equivalentes, foram denominados de "Granito Tipo Teles Pires", mas sabemos que vários desses granitos podem corresponder a eventos magmáticos muito mais jovens ou mesmo mais antigos, sendo portanto de dificil separação. Assim como os tipos litológicos denominados de Granito Tipo Maloquinha apresentam equivalências petrográficas aos do Granito Tipo Teles Pires.

Agradecimentos Externamos nossos agradecimentos ao geólogo Otto Bittencourt Netto, Superintendente Técnico Operacional do Projeto RADAMBRASIL, pelo incentivo à preparação desta compilação, do mesmo modo que ao geólogo José Ferreira de Souza, chefe do $8 .^{\circ}$ distrito do DNPM. Agradecemos também aos colegas Caubi André Caldeira Fernandes e Vital José Ribeiro Wanderley, pela leitura e críticas deste trabalho, e a todos aqueles que direta ou indiretamente contribuíram para a sua realização.'

Somos gratos também aos colegas do Instituto de Geocronologia da USP, pela realização da maior parte das datações apresentadas neste trabalho.

\section{BIBLIOGRAFIA}

ABREU, F.A.M. de - 1978 - O Super Grupo Baixo Araguaia. In : CONGRESSO BRASILEIRO DE GEOLOGIA, 30. $0^{\circ}$ Recife. Anais... Recife, Sociedade Brasileira de Geologia, V.2., p. 539-545.

ACKERMAN, F.L. - 1948 - Recursos minerais do Território Federal do Amapá. Rio de Janeiro. Impr. Nacional. 30p.

ALBUQUERQUE, O.R. de - 1922 - Reconhecimentos geológicos no Vale do Amazonas. B. Serv. Geol. Mineralógico, Rio de Janeiro, (3) 84p.

ALMEIDA, F.F.M. de - 1965 - Geossinclineo Paraguaio. Sedegeo, Porto Alegre, 1: 87-101.

ALMEIDA, F.F.M. de - 1967 - Origem e evolução da Plataforma Brasileira. B. Div. Geol. Mineral, Rio de Janeiro, (241), 36p.

ALMEIDA, F.F.M. de - 1974 - Evolução tectônica do Craton do Guaporé comparada com a do escudo Báltico. R. Bras. Geoci., São Paulo, 4 (3): 191-204.

ALMEIDA, F.F.M. de - 1978 - A evolução dos cratons Amazônico e do São Francisco comparada com seus homólogos do Hemisfério Norte. In: CONGRESSO BRASILEIRO DE GEOLOGIA, 30., Recife. Anais ... Recife, Sociedade Brasileira de Geologia, V. 6, p. 2392-2407.

ALMEIDA, F.F.M. de; MARTIN, F.C.; FERREIRA, E.O. e FURQUE, G. Mapa Tectônico da América do Sul. Nota Explicativa. Brasília. B. DNPM/UNESCO, 20p.

ALMEIDA, F.F.M. de \& NOGUEIRA FILHO, J. do V. - $1969-$ Reconhecimento geológico do Rio Aripuanã. B. Div. Geol. Mineral., Rio de Janeiro, (199): 1-43.

AMARAL, G - 1971 - Considerações sobre a evolução tectônica da Amazônia no Pré-Cambriano. In: CONGRESSO BRASILEIRO DE GEOLOGIA, 25.", São Paulo. Resumo das comunicações. (Boletim Especial, 1) p. 161-162.
AMARAL, G. - 1974 - Geologia Pré-cambriana da região amazônica. São Paulo, Universidade, Instituto de Geociências, 212p. (Tese de livre docêncla).

ANDERSON, C.W. \& DUNN, W.A. - 1895 - The conglomerate prospecting expedition, Georgetown. (Governament of British Guiana, Admt. (Rept.).

ANHAEUSSER, C.R.; MASON, R.; VILJOEN, M.J. P VILJOEN, R.P. - 1969 - A reappraisal of some aspects of Precambrian Shield Geology. Bull. Geol. Soc. Am., 80p. 2175-2200.

ARAÚJO, H.J.T. de; RODARTE, J.B.M.; DEL'ARCO, J.O.; SANTOS, D.B. dos; BARROS, A.M.; TASSINARI; C.C.G.; LIMA, M.I.C. de; ABREU, A.S. e FERNANDES, C.A.C. -1978 - Geologia. In: Brasil. Departamento Nacional da Produção Mineral. Projeto RADAMBRASIL. Folha SB.20 Purus. Rio de Janeiro (Levantamento de Recursos Naturais, 17).

ARAÚJO, J.F.V. de; MONTALVÃO, R.M.G. de; LIMA, M.I.C. de; FERNANDES, P.E.C.A.; CUNHA, F.M.B. da; FERNANDES C.A.C. e BASEI, M.A.S. - 1976 - Geologia. In: Brasil. Departamento Nacional da Produção Mineral. Projeto RADAMBRASIL. Folha SA.21 Santarém. Rio de Janeiro (Levantamento de Recursos Naturais, 10).

AUbOUIN, J, - 1965 - Geosynclines. Elsevier Publishing Company, Amsterdam - London - New York, 67 fig., 335p. xerox.

BARBOSA, O - 1955 - CONGRESSO BRASILEIRO DE GEOLOGIA 9. ${ }^{\circ}$ Araxá, Guia das excursões, Belo Horizonte, Soc. Bras. Geol. (Noticiário 3).

BARBOSA, O. - 1966 - Geologia básica e econôtnica da região do médio Tapajós. Estado do Pará. B. Div. Fom. Prod. Mineral, Rio de Janeiro, $126,55 \mathrm{p}$. 
BARBOSA, O.; GOMES, F.A.; HELMBOLD, R, e RAMOS, J.R. de A. - 1966 - Geologia estratigráfica, estrutural e econômica da área do Projeto Araguaia. Monografia, Div. Geol. Mineralogia, Rio de Janeiro, 19, 95p:

BARBOSA, O. \& RAMOS, J.R. de A. - 1959 - Território do Rio Branco aspectos principa is da geomorfologia, da geologia e das possibilidades minerais de sua zona setentrional. B. Div. Geol. Mineral, Rio de Janeiro, 196, 49p

BASEI, M.A.S. - 1973-Geocronologia: SB.22/SC.22 Belèm, Projeto RADAM, 3p., datilografado.

BASEI, M.A.S. - 1975 - Geocronologia do Território Federal de Roraima e parte norte do Estado do Amazonas. Belém, Projeto RADAMm n.p. (Relatório interno RADAM, 24-G).

BASEI: M.A.S - 1977 - Idade do Vulcanismo Ácido - Intermediário na região amazônica, São Paulo, Universidade, Instituto de Geociências, 133p., figs., tab., mapa (dissertação de mestrado).

BARROS, A.M.; ALVES, E.D. de O, ; ARAÚJO, J.F.V.; LIMA, M.I.C de e FERNANDES, C.A.C. Geologia. In: Brasil. Departamento Nacional da Produção Mineral. Projeto RADAMBRASIL. Folha SB.18 Javari e SC.18 Contamana. Rio de Janeiro (Levantamento de Recursos Naturais, 13).

BEISIEGEL, V. de R.; BERNADELLI, A.L.; DRUMMOND, N.F. RUFF, A.W. e TREMAINE, J.W. - 1973-Geologia e recurso minerais da Serra dos Carajás. R. Bras. Geoc., São Paulo, (3), p. 215-242, xerox.

BERRANGE, J.P. - 1967 - Progress report on photogeological mapping of Guyana south of $4 .^{\circ}$, latitude operation Eldorado, London, Inst. Geol. Sci.

BONFIM, L.F.C. et alii - 1974 - Projeto Rorama: relatório tinal. Ma naus. DNPM/CPRM, 1974, 10v. in 15

BOUMAN, Q.C. - 1959 - Roraima formation: northern part of the território do Rio Branco. Belém. PETROBRÁS-RENOR. jul., 17p (Relatório técnico interno, 350-A).

BRASIL. Departamento Nacional da Produção Mineral - 1975 - Carta Geológica do Brasil ao milionésimo. Folha Tocantins (SC.22). Nota explicativa, Brasília, 58p.

BRASIL. Superintendềncia de Desenvolvimento da Amazônia. Departamento de Recursos Naturais - 1972 - Pesquisa mineral do Iriri-Curúa ; relatório preliminar. Belém, A.P.C., Divisão de Documenta. ç̃o, 62p. anexo mapas.

BRAUN, O.P.G. \& RAMGRAB, G. - 1972 - Geologia do território de Roraima. In: CONGRESSO BRASILEIRO DE GEOLOGIA, 26.", Belém, resumo das comunicações. Simpósios. Belém, Sociedade Brasileira de Geologia (Boletim, 2) p. 68-70.

CAPUTO, M.V.; RODRIGUES, R. e VASCONCELOS, D.N.N. de - 197 - Litoestratigrafia da Bacia do Amazonas. Belém, PETROBRÁS-RENOR. (Relatório técnico interno, 614-A)

CAPUTO, M.V. \& SAD, A.R.E. - 1974 - Geologia do Baixo Rio Negro e trecho da estrada BR-174. Belém, PETROBRÁS-RENOR, n.p. (Relatório técnico interno, 589-A).

CARNEIRO; R.G.; ANDRADE, F.G.; SHLVA, G.O.P. - 1968 - Reconhecimento geológico no Território Federal de Roraima (Graben do Takutu). Belém, PETROBRÁS-RENOR. (Relatório técnico interno, 122-G)

COMPANHIA VALE DO RIO DOCE/COMPANHIA MERIDIONAL DE MINERACÃO - 1972 - Distrito ferrifero da Serra dos Carajás. In: CONGRESSO BRASILEIRO DE GEOLOGIA, 26,", Belém, resuma das comunicações. Simpósios. Belém, Sociedade Brasileira de Geologia, 100p (Boletim, 2) p. 78-80.

DAEMON, R.F. \& CONTREIRAS, C.J.A. - 1971 - Zoneamento palinológico da bacia do Amazonas. Belém, PETROBRÁS-RENOR. n.p. (Relatório técnico interno, 635-A).

DALL'AGNOL, R. et alii - 1978 - Granito Surucucu. In : CONFEREN CIA GEOLÓGICA INTER GUIANAS, 10, ${ }^{\circ}$ Belém. Anais... Belém, Departamento Nacional da Produção Mineral. p. 340-388.

DEL'ARCO, J.O. ; SANTOS, R.O.B. dos; RIVETTI, M. ; ALVES, E.D.). FERNANDES, C.A.C. e SILVA, L.L. da - 1977 - Geologia. In Brasil. Departamento Nacional da Produção Mineral. Projeto RA DAMBRASIL. Folha SB.19 Juruá. Rio de Janeiro. (Levantamento de Recursos Naturais, 15).

DALTON, L.V. - 1912 - On the geology of Venezuela. Geol. Mag., London, 9: 203-210.

DANNI, J.C.M. e RIBEIRO, C.C. - 1978 - Caracterização estratigráfica da sequiência vulcano-sedimentar de Pilar de Goiás e de Guarinos, Goiás. In: CONGRESSO BRASILEIRO DE GEOLOGIA, 30." Recife. Anais ... Recife, Sociedade Brasileira de Geologia, p. 582.596.

DEQUECH, V. - 1943 - Comissão para o estudo das jazidas auriferas do Urucumacuman; relatório final. Rio de Janeiro, DNPM/DFPM, 57p (Relatório do Arquivo Técnico da DGM, 765).
DERBY, O.A. - 1877 - Contribuição para a geologia da região do Baixo Amazonas. Arch. Mus. Nac., Rio de Janeiro, 2: 77.104.

DERBY, O.A. - $1898-$ O rio Trombetas. B. Mus. Paraense Hist. Natural Ethnogr., Belém, 2(3): 366-382.

DREHER, A.M ; ARAÚJO J.F.V.; ABREU, A.S. - 1976 - Associação básico anortosittca dos rios Curuquetê e Ciriquiqui; município de Lábrea, Estado do Amazonas. In: CONGRESSO BRASILEIRO DE GEOLOGIA, 29. , Ouro Preto. Resumo dos Trabalhos. Ouro Preto, p. 191 .

FERNANDES, C.A.C. e MORAIS, U.N. de - 1975 - Operação Bateria; relatório (RADAM/NUCLEBRÁS). Belém, Projeto RADAMBRASIL. n.p. (Relatório interno RADAMBRASIL, 53-G)

FERREIRA, E.O. - 1959 - Contribuição a litologia da série Uatumã. B. Div. Geol. Mineralogia, Rio de Janeiro, 185. $31 \mathrm{p}$

FERREIRA, E.O. - 1969 - Considerações sobre o mapa tectônico do Brasil e sobre a tectônica da plataforma brasileira. In : CONGRESSO BRASILEIRO DE GEOLOGIA, 23. , Salvador. Resumo das conferências e comunicações. Salvador, Soc. Bras. Geol. (Boletim Especial, 1), p. 73-75

FERREIRA, E.O. - 1972 - Carta Tectônica do Brasil; noticia explicativa. B. DNPM, Rio de Janeiro, (1), 19p

FORMAN, J.M.A. - 1969 - Projeto Trombetas-Maruru - Reconhecimento geológico detalhado do rio Trombetas. Rio de Janeiro, GEOMINEERAÇAO/DNPM - 59p. datil

FRANCISCO, B.H.R.; SILVA, G.G. da; ARAÚJO, G.G. - 1967 - Estudos geológicos e observações geográficas no Baixo Tocantins, Municipio de Tucuruí e Baião, Estado do Pará. In : Atas do simpósio sobre a biota amazônica. Rio de Janeiro, Conselho Nacional de Pesquisa, Y. 1: Geociências, p. 35.67

FREYDANK, H.G. - 1957 - Limited investigation along easthern and southern flank of the Monte Alegre Dome. Belém, PETROBRÁS-RENOR. n.p. (Relatório técnico interno, 165-A).

GUIMAR Z̃ES, D. -1930 - A província magmática do Roraima, Brasil septentrional. B. Serv. Geol. Mineral, Rio de Janeiro, 45, 5tp.

GEOMINERAÇÃO LTDA - 1972 - Projeto Mapuera; reconhecimento geológico/geoquímico. S.1/ICOMI, $101 \mathrm{p}$.

GLICKSON, A.Y. - 1972 - Early precambrian evidence of a primitive ocean crust and Island nuclei of sodic granite. Geological Society of America Bulletin, v. 83, p. 3323-3344. 12 fig. xerox.

GOMES, C.B.; CORDANI, U.G.; BASEI, M.A.S. - 1975 - Radiometric ages from the Serra dos Carajás área, northern Brazil. Geological of America Bulletin, Colorado 86: $939-942$.

HARTT, C.F. - 1896'- A geologia do Pará B. Mus. Paraense His. Natural Ethnogr. Belém, 1: 257-273.

HASUI, Y.; ABREU, F.A.M. de;SILVA, J.M.R. da - 1977 - Estratigrafia da Faixa de Dobramentos Paraguai-Araguaia no centro-norte do Brasil. Bol. I.G. Instituto de Geociências da Universidade de São Paulo. 6: 77.83 .

HIDROSERVICE - Engenharia de Projetos Ltda. - 1973 - Plano de desenvolvimento integrado da área da bacia do rio Tocantins, Belém, SUDAM. 3v, in 6t il, mapas (Relatório HE - 156 - rio - 0872).

IANHEZ, A.C. \& MONTALVĂO, R.M.G. de - 1978 - Reconhecimento geológico das estradas e oeste do rio Araguaia, nas Folhas SC.22-X-B, SC.22-X-A, SC.22-X-C e SC.22-V-B. Goiânia, Projeto RADAMBRASIL. n.p. datil. (Relatório técnico interno).

ISSLER, R.S. - 1973 - Observações sobre a geologia do mosaico Araguaia (SB.22). Belém, Projeto RADAM, 15p., mapa, datilografado.

ISSLER, R.S. - 1974 - Esboço geológico-tectônico do craton do Guaporé. In: CONGRESSO BRASILEIRO DE GEOLOGIA, $28 .^{\circ}$, Porto Alegre. Resumo das comunicações. Porto Alegre, Soc. Bras. Geol. (Boletim, J) p. 659-665.

ISSLER, R.S. - 1977 - Esboço geológico-tectônico do craton do Guaporé. R. Bras. Geol., São Paulo, 7(3): 177-212.

ISSLER, R.S.; ANDRADE, A.R.F.; MONTALVÃO, R.M.G. de; GUIMARÃES, G.; SILVA, G.G. da e LIMA, M.I.C de - 1974 - Geologia. In: Brasil. Departamento Nacional da Produção Mineral, Projeto RADAMBRASIL. Folha SA.22 Belém. Rio de Janeiro. (Levantamento de Recursos Naturais, 5)

JOĀO, X. da S.J.; FRIZZO, S.J.; REIS, R.M.; MARINHO, P.A.C.; ARAÚJO, O.J.B. de; REZENDE, N.G.A.M.; VALE, A.G. e MARTINS, R.C. - 1975 - Geologia e geoquímica da área Gradaús-Nova Olinda. Belém, CPRM 3v. (Relatório do Arquivo Técnico da DGM, 2440) xerox.

KISTLER, P - 1954 - Historical resume of the Basin. Belem, PETROBRÁS-RENOR, n.p. ;(Relatório técnico interno, 104-A).

KLOOSTERMAN, J.B. - 1966 - Granites and rhyolites of São Lourenço, a vulcano-plutonic complex in southern Amazônia. Eng. Miner. Metal., Rio de Janeiro, 44 (262): 169-171. 
KLOOSTERMAN, J.B. - 1967 - Ring structures in the Oriente and Massagana granite complexes, Rondônia, Brasil. Eng. Miner. Metal., Rio de Janeiro, 45 (266): 73-77.

KLOOSTERMAN, J.B. - 1968 - Uma provincia do tipo nigeriano no sul da Amazônia. Eng. Min. Metal., Rio de.Janeiro, 47 (278): 59-64; 47 (280): 167-168.

KNUP, P.E. - 1971 - Reconhecimento geológico na região dos rios Ita caiunas e Tocantins, Estado do Pará. In: CONGRESSO BRASILEIRO DE GEOLOGIA, 25. ${ }^{\circ}$, São Paulo. Resumo das comunicações. Sảo Paulo, Sociedade Brasileira de Geologia. 261 p. (Boletim especial, 1) p. 61-62.

KRATZ, K.O. \& GLEBOVITSKI, V.A. $-1972-$ Metamorphic Belts of the USSR. In: INTERNATIONAL GEOLOGICAL CONGRESS, 24..$^{\circ}$ Moscou, section 1, p. 348-353.

LASA ENGENHARIA E PROSPECÇÖES S.A. - 1964 - Pesquisa de cassiterita no Território Federal de Rondônia; relatório preliminar: Av. Div. Fom. Prod. Mineral, Rio de Janeiro, (88). $62 \mathrm{p}$

LEAL, J.W.L.; SILVA, G.H.; SALUM, O.A.L.; SILVA, L.L. de; DREHER, A.M. e BASEI, M.A.S. - 1974 - Esboço geológico de parte da Folha SC.20 Porto Velho. In: CONGRESSO BRASILEIRO DE GEOLOGIA, 28. ${ }^{\circ}$, Porto Alegre. Anais... Porto Alegre, Sociedade Brasileira de Geologia. v.4 p. 247-269.

LEAL, J.W.L.; SILVA, G.H, ; ABREU; A.S. e LIMA, M.I.C. de - $1976-$ Granito Serra da Providência. In : CONGRESSO BRASILEIRO DE GEOLOGIA, 29. , Ouro Preto, resumo dos trabalhos. Ouro Preto, p. $\cdot 191$.

LEAL, J.W. L. ; SILVA, G.H. ; SANTOS, D.B. dos; TEIXEIRA, W. ; LIMA M.I.C, de; FERNANDES, C.A.C.; PINTO, A. do C. - 1978 - Geologia. In: Brasil. Departamento Nacional da Produção Mineral, Projeto RADAMBRASIL. Folha SC.20 Porto Velho. Rio de Janeiro. (Levantamento de Recursos Naturais, 16)

LEITE, D.C. - 1958 - Detailed geologic investigations of northwestern Território do Acre (serra do Moa, Jaquirana, headwaters of rio Javari) Belém, PETROBRÁS-RENOR, 58p. (Relatório técnico interno, $281-\mathrm{A})$.

LIBERATORE, G.; ALECRIM, J.D.; MEDEIROS, J.B. de; MALOUF, R.F.; PINHEIRO, S. de S.; ACHĀO, S.M. e SANTOS, J.O.S. - 1972 - Projeto Aripuanã-Sucunduri; relatório final. Manaus, DNPM/ CPRM, 8v.

LIMA, M.I.C. de; MONTALVAO, R.M.G. de; ISSLER, R.S.; OLIVEIRA, A. da S.; BASEI, M. A.S.; ARAÚJO, J.F.V. e SILVA, G.G. da 1974 - Geologia. In: Brasil. Departamento Nacional da Produção Mineral, Projeto RADAMBRASIL. Folha NA/NB.22 Macapá. Rio de Janeiro. (Levantamento de Recursos Naturais, 6).

LIMA, P.F.C.; RODRIGUES, A.P. e LEMOS, D.B. - 1975 - Projeto Apiacás-Caiabis; reconhecimento geológico; relatório final integrado. Goiânia, DNPM/CPRM. 4v. (Relatório do Arquivo Técnico da DGM, 2499).

LOURENCY, R.S.; MONTALVÃo, R.M.G. de; PINHEIRO, S. da S.; FERNANDES, P.E.C.A.; PEREIRA, E.R.; FERNANDES, C.A.C e TEIXEIRA, W. - 1978 - Geologia. In : Brasil. Departamento Nacional da Produção Mineral, Projeto RADAMBRASIL. Folha SA.20 Manaus. Rio de Janeiro. (Levantamento de Recursos Naturais, 18).

LOBATO, F.P.N.S.; APPEL, L.E.; GODOY, M.C.F.T:; RITTER, J.E. - 1966 - Pesquisa de cassiterita no Território Federal de Rondônia; relatório final. B.Div. Fom, Prod. Mineral. Rio de Janeiro (125). 209p.

MAROTTA, C.A. et alii - 1966 - Notas sobre o distrito manganesífero da Serra do Navio, Território Federal do Amapá, Brasil. Av. Div. Geol. Mineralogia, Rio de Janeiro, 41 : $57-68$.

MARTIN-KAYE, P.H.A. - 1966 - Progress by the Geological Survey of British Guyana. Av. Div. Geol. Mineral. Rio de Janeiro, 41 : 113-121.

McCONNEL, R.B. et alij-1964-A new interpretation of the geology of British Guyana. Nature, London, 204 (4954): 115-118.

McDOUGALL, I. ; COMPSTON, W. ; HAWKES, D.D. - 1963 - Leakage of radiogenic argon and strontiun from minerals in proterozoic dole. rites from British Guyana. Nature, London, 198 (4880): 564-567.

McGREGOR, A.M. - 1951 - Some milestones in the Precambrian of sou. thern Rhodesia: Geol. Soc. S. Africa Proc., v. 54, p. XXVII-LXXI, xerox.

MIKHAYLOV, A. -1970 - The development of geossynclines and folding. Internat. Geology. Rev. Washington. 12(12). 1490-1495.

MIYASHIKO, A. - 1973 - Metamorphism and metamorphic belts. George 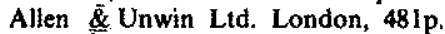

MONTALVÃ̃o, R.M.G. de - 1975 - Grupo Uatumã no Craton Guianês. In: CONFERENCIA GEOLOGICA INTERGUIANAS, $10^{\circ}$, Belém. Anais... Belém. Departamento Nacional da Produção Mineral.

MONTALVÄO, R.M.G. de - 1976 - Esboço Geológico-Tectónico do Craton Guianês. R. Bras. Geoci., São Paulo, v.6. 230-245.
MONTALVÃo, R.M.G. de e ABREU, A.S. - 1975-Sienito Mutum relatório preliminar. Belém, Projeto RADAM. n.p. (Relatório interno RADAM, 36-G)

MONTALVÃO, R.M.G. de e FERNANDES, P.E.C.A. - 1975 - Grupo Tunui. Belém, Projeto RADAM. n.p. (Relatório interno RADAM, 38-G).

MONTALVÃO, R.M.G. de e PITTHAN, J.H.L. - 1974 - Grupo Cauarane. Belém, Projeto RADAM, 7p. (Relatório interno RADAM, 44-G).

MONTALVÃO, R.M.G. de; MUNIZ, M. de B.; ISSLER, R.S.; DALL' AGNOLL, R.; LIMA, M.I.C. de; FERNANDES, P.E.C.A. e SILVA G.G. da - 1975 - Geologia. In: Brasil. Departamento Nacional da Produção Mineral, Projeto RADAMBRASIL. Folha NA.20 Boa Vista e parte das Folhas NA.21 Tumucumaque, NB.20 Roraima NB.21 Rio de Janeiro. (Levantamento de Recursos Naturais, 8).

MONTALVÃO, R.M.G. de; BEZERRA, P.E.L. ; FERNANDES, C.A.C. SIl.VA, G.H. e PIMENTA, O.N. dos S. - 1979a - Granitos pós-cinemáticos das Folhas SB.20 Purus, SC.20 Porto Velho e SC.21 Juruena (Plataforma Amazônica). Goiânia. B. Soc. Bras. Geol. núcleo CentroOeste, 9: 44-73.

MONTALVÃO, R.M.G. de; IANHEZ, A.C.; BEZERRA, P.E.L.; TAKAHASHI, R.; PALMEIRA, R.C. de B. - 1979b-Serra do Inajá Provável estrutura "Arqueana" Gọânia, Projeto RADAMBRASIL. n.p. (Relatório técnico interno; 223-G).

MONTALVÃO, R.M.G. de; SILVA, G.H.; PIMENTA, O.N. dos S. e BEZERRA, P.E.L. - $1979 \mathrm{c}$ - Coberturas Sedimentares e VulcanoSedimentares Pré-Cambrianas das Folhas SB.20 Purus, SC.20 Porto Velho e SC.21 Juruena (Plataforma Amazônica). Goiânia, Projeto RADAMBRASIL. 15p. mapa. (Relatório técnico interno).

MOURA, P. e WANDERLEY, A. - 1938 - Noroeste do Acre; reconhecimento geológicos para petróleo. B. Serv. Fom. Prod. Mineral., Rio de Janeiro, 26: 1-116.

MUNIZ, M. de B. et alii - 1974 - Geologia do Território Brasileiro nas Folhas Boa Vista (NA.20), Roraima (NB.20/21) e parte da Folha Tumucumaque (NA.21) Belém, Projeto RADAM, 183p. (Relatório interno RADAM, 21-G).

MURATOV, M.V. - 1972 - Principal types of basms of ancient platforms and the problem of their origin. Internal. Geology Rev. Washington. V. $16(2)$, p. 125-132. Xerox.

NAGELL, R.H. - 1962 - Geology of the Serra do Navio, manganese district, Brazil. Econ. Geol., Lancaster, 57(4): 481-498.

NAGELL, R.H. e SILVA, A.R.O. - 1961 - Carbonato de manganês como protominério do depósito da Serra do Navio, Território Federal do Amapá. B. Soc. Bras. Geol: São Paulo, 10(2): 53-59.

OLIVEIRA, A.I. de - 1929 - Bacia do Rio Branco, Estado do Amazonas. B. Serv. Geol. Mineral., Rio de Janeiro, 37, 71p.

OLIVEIRA, A. da S.; FERNANDES, C.A.C.; ISSLER, R.S.; ABREÜ, A.S.; MONTALVÃO, R.M.G. de e TEIXEIRA, W. - 1975-Geologia. In: Brasil. Departamento Nacional da Produção Mineral, Projeto RADAMBRASIL. Folha NA.21 Tumucumaque e parte da Folha NB.21 Rio de Janeiro. (Levantamento de Recursos Naturais, 9).

OLIVEIRA, A.I. de e LEONARDOS, O.H. - 1943 - Geologia do Brasil. 2 ed. Rio de Janeiro, Serviço de Informação Agrícola, 813p. (Série didática, 2).

OLIVEIRA, E.P. de - 1915/1918 - Geologia, 1, Estudos feitos sobre amostras de rochas colhidas no sertão de Mato Grosso. 2. Monografia sobre o gesso (Geologia Econômica) ocorrências, explorações e úsos. Rio.de Janeiro. Pap. Macedo. 59p. (Brasil. Commissão de Linhas Telegráphicas Estratégicas de Mato Grosso do Amazonas. Anexo 5. Publ. 59).

PADILHA, A.V.; MONTES, A. de S. L. ; LEMOS, D.B.; FROTA, G.B.; LUZ, J. da S.; MOREIRA, J.M.P.; MORENO, J.J.P.; MONTES, M.L.; MENEZES FILHO, N.R.M.; CARDOSO, O.R.F.; LIMA, P.F.C.; ALMEIDA, W.J. de; ABREU FILHO, W.; SILVEIRA, W.P. e SANTANA, W.R.R. - 1975 - Projeto Centro-Oeste de Mato Grosso; relatório final. Goiânia, DNPM/CPRM. V.2. (Relatório do Arquivo Técnico da DGM, 2220).

PAIVA, G. de - 1929 - Valle do Rio Negro; physiografia e geologia. B. Serv. Geol. Mineral., Rio de Janeiro. 40, 62p

PAIVA, G. de - 1939 - Alto Rio Branco. B. Serv. Geol. Mineral.. Rio de Janeiro, 99, 44p.

PAIVA, G. de - 1946 - Relatório preliminar de visita feita nos depósitos de manganés da Serra do Navio e cercanias do Rio Amapari, apresentando ao governo do Território Federal do Amapá. Rio de Janeiro. DNPM, n.p. dat.

PARADA, J.M. et alii - 1966 - Pesquisas minerais no Estado do Pará, B. Div. Geol. Mineralogia, Rio de Janeiro, 235, 44p.

PARA/IDESP - 1972 - Projeto Rio Fresco; contribuição à geologia do pré-cambriano da Amazônia. In: CONGRESSO BRASILEIRO DE 
GEOLOGIA, 26. ${ }^{\circ}$, Belém. Resumo das comunicações. Simpósios, Sociedade Brasileira de Geologia. 100p. (Bol. 2) p. 73-75.

PESSOA, M.R.; SANTIAGO, A.F.; ANDRADE, A.F. de; BARRETO E.L.; NASCIMENTO, J.O.; OLIVEIRA, J.R.; LOPES, R.C. PRAZERES, W.V. - 1977 - Projeto Jamaxin; relatório final. Manaus, DNPM/CPRM, $8 \mathrm{v}$,

PINHEIRO, S. da S. ; FERNANDES, P.E.C.A.; PEREIRA, E.R.; VAS CONCELOS, E.G.; PINTO, A. do C.; MONTALVÃO, R.M.G. de ISSLER, R.S.; DALL'AGNOL, R.; TEIXEIRA, W. e FERNANDES, C.A.C. - 1976 - Geologia. In : Brasil. Departamento Nacional da Produção Mineral, Pròjeto RADAMBRASJL. Folha NA.19 Pico da Neblina. Rio de Janeiro. (Levantamentos de Recursos Naturais, 11)

PINTO FILHO, F.P.P.; FREITAS, A.F. de; MELO, C.F. de; SILVA, L.M.; LOBATO, O.G. e ROMANINI, S.J. - 1976-Projeto Sudeste de Rondônia, relatório de progresso 02. Porto Velho. $2 \mathrm{p}$. (Relatório do Arquivo Técnico da DGM)

PRIEM, H.N.A ; BOELRIJK, N.A.I.M.; HEBEDA, F.H. e VERDURMEN, E.A. Th., VERSHURE, R.H. e BON, E.H. - 1971 - Granitic complexes and associated tin mineralizations of Grenville age in Rondônia, Wertern Brasil. Bol. Geol. Soc. Am., New York, 82: 1095-I102.

RAMGRAB, G.E.: BONFIM, L.F.C.; MANDETTA, P. - 1972 - Projeto Roraima, 2." fase. Manaus, DNPM/CPRM, v.2.

RAMGRAB, G.E. e SANTOS, J.O.S, - 1974 - o Grupo Uatumã, sessão geológica regional. In: CONGRESSO BRASILEIRO DE GEOLOGIA, 28. ${ }^{\circ}$, Porto Alegre. Anais ... Porto Alegre, Sociedade Brasileira de Geologia, v.2. p. 87-95.

RAMOS, J.R. de A. - 1955 - Reconhecimento geológico do Alto Rio Fresco, Estado do Pará. Relat. An. Div. Geol. Mineralogia, Rio de Janeiro, 32-48. Mapa.

ZAMOS, J.R. de A. - 1967 - Estratigrafia da região Xingu-Tocantins. In: Atas do Simpósio sobre a bióta Amazônica. Rio de Janeiro, Conselho Nacional de Pesquisa. V.1: Geociências, p. 373-386.

REID, A.R. - 1972 - Stratigraphy of the type area of the Roraima Group, Venezuela. In: CONFERENCIA GEOLOGICA INTER-GUAYANAS, 9.", Guayana. Memoria ... Guayana, Ministério de Minas e Hidrocarburos. (Boletim de Geologia. Pubi. Espec., 6) p. 342-353.

SABOIA, L.A. de - 1979 - Os "Greenstone Belts" de Crixás e Goiás-Go. Bol. Inf. Soc. Bras. Geol., núcleo Centro-Oeste, Goiânia (9): 43-73, março.

SALOP, L.L. e SCHEINMANN, Y.M. - 1969 - Tectonic history and structures of platforms and shields. Tectnophysics, Amsterdam, 7(5/6): 565-597, 1969

SANTOS, D.B. dos -1977 - O Grupo Beneficente. Belém, Projeto RADAMBRASIL, 7p. (Relatório interno RADAMBRASIL, 128-G).

SANTOS, D.B. dos; FERNANDES, P.E.C.A.; DREHER, A.M.; CUNHA F.M.B. da e BÁSEI, M.A.S. - 1974 - Esboço geológico da Folha SB.21 Tapajós. In: CONGRESSO BRASILEIRO DE GEOLOGIA 28. ${ }^{\circ}$, Porto Alegre. Anais... Porto Alegre, Soc. Bras. Geol., v. 4 , p. $269-277$

SANTOS, D.B. dos; FERNANDES, P.E.C.A.; DREHER, A.M.; CU NHA, F.M.B. da; BASEI, M.A.J. e TEIXEIRA, 3.B.G. - 1975 Geologia. In: Brasil. Departamento Nacional da Produção Mineral Projeto RADAM. Folha SB.21 Tapajos, Rio de Janeiro. (Levantamento de Recursos Nalurais, 7).

SANTOS, J.O.S. et alii - 1974 - Projeto Norte da Amazônia - Domínio Baixo.do Rio Negro; relatório final. Manaus, DNPM/CPRM, $8 \mathrm{v}$

SANTOS, J.O.S. e OLIVEIRA, J.R. - Magmatismo básico-alcalino no Proterozóico superior da Plataforma Amażônica. In : CONGRESSO BRASILEIRO DE GEOLOGIA, 30. , Recife. Anais ... Recife, Sociedade Brasileira de Geologia. V.1. p. 1309-1323.
SANTOS, J.O.S. e SALAS, H.T. - 1974 - Notas sobre a primeira ocorrência de rochas alcalinas no Território Federal de Roraima. In : CONGRESSO BRASILEIRO DE GEOLOGIA, 28. ${ }^{\circ}$, Porto Alegre. Resumo das comunicações. Porto Alegre, Sociedade Brasileira de Geologia. (Boletim, 1) p. 412-413

SCARPELLI, W. - 1966 - Aspectos genéticos e metamórficos das rochas do distrito da Serra do Navio; Território Federal do Amapá. Av. Div. Geol. Mineralogia. Rio de Janeiro, 41:37-55.

SILVA, G.G. da; LIMA, M.I.C. de; ANDRADE, A.R.F. de; ISSLER, R.S. e GUIMARÃES, G. -1974 - Geologia. In: Brasil. Departamento Nacional da Produção Mineral, Projeto RADAM. Fotha SB.22 Araguaia e parte da SC.22. Tocantins. Rio de Janeiro (Levantamento de Recursos Naturais, 4).

SILVA, G.H, ; LEAL, J.W.L.; SALUM, O.A.L.; DALLAGNOL, R. e BASEI, M.A.S. - 1974 - Esboço geológico de parte da Folha SC. 21 Juruena. In: CONGRESSO BRASILEIRO DE GEOLOGIA, 28., Pórto Alegre. Anais... Porto Alegre, Socieda de Brasileira de Geologia. v. 4, p. 299-309.

SILVA, G.H.; LEAL, J.W.L.; MONTALVÃO, R.M.G.; BEZERRA, P.E.L.: PIMENTA, O.N dos S.: FERNANDES, C.A.C. P TASSINARI, C.C.G. - no prélo - Geologia. In : Brasil. Departamento Nacional da Produção Mineral, Projeto RADAMBRASIL. Folha SC.21 Juruena. Rio de Janeiro. (Levantamento de Recursos Naturais, 19).

SILVA, L.L, da: RIVETTI, M.: DELL'ARCO, J.O : ALMEIDA, L.F.G. de; DREHER, A.M. e TASSINARI, C.C.G. - 1976 - Geologia. In : Brasil. Departamento Nacional da Produção Mineral. Projeto RA. DAMBRASIL. Folha SC.19 Rio Branco. Rio de Janeiro. (Levantan mento de Recursos Naturais. 12).

SNELL.ING, N.J. - 1963 - Age of the Roraima Formation, British Guyana. Nature. London, 198 (4885): 1079-1080.

SOUZA, E.C. et alii - 1975 - Projeto Noraeste de Rondônia; relatório final. s.1. DNPM/CPRM. v.1. (Relatório do Arquivo Técnico da DGM, 2548).

SUSZCZYNSKI, E.F. - 1969 - Certas considerações sobre a tectônica da plataforma Amazônicat Iñ: CONGRESSO BRASILEIRO DE GEOLOGIA, 23. ${ }^{\circ}$, Salvador. Resumo das conferências e comunicações. Salvador, Sociedade Brasileira de Geologia. (Boletim especial, 1).

SUSZCZYNSKI, E.F. - 1970 - La geologie et la tectonique de la plataforme Amazonienne. Geol. Rundschau, Stuttgart, 59(3); 1232-1253.

SUSZCZYNSKI, E.F. - 1972 - Origem vulcânica do minério de ferro primário da Serra dos Carajás, Pará. In : CONGRESSO BRASILEIRO DE GEOLOGIA, 26..$^{\circ}$ Belém, out. Anais .. Belém, Sociedade Brasileira de Geologia. V.1. 103-109. Xerox.

SWAN, A.G. - 1958 - Geology of lower Rio Negro area. Belém, PETROBRÁs-RENOR. n.p. (Relatório técnico interno, 214-A).

TEIXEIRA, W. \& BASEI, M.A.S - 1975 - Geocronologia da Folha NA.21 Tumucumaque. Belém, Projeto RADAM. (Relatório interno RADAM, 45-G).

TEIXEIRA, W. \& TASSINARI, C.C.G. - 1977 - Estudo Geocronológico $\mathrm{Rb} / \mathrm{Sr}$ e K/Ar da Folha SC.20 Porto Velho. 34p. (Relatório interno RADAMBRASIL, . 127,G).

TEIXEIRA, W. - 1978 - Significação tectônica do magmatismo anorogênico precambriano básico e alcalino na região Amazônıca. In : CONGRESSO BRASILEIRO DE GEOLOGIA, 30. ${ }^{\circ}$, Recife. Anais.. Recife. Sociedade Brasileira de Geologia. V.1. p. $491-506$.

TOLBERT, G.E.; TREMAINE, J.W.; MELCHER, G.C. and GOMES, C.B. $-1970-$ Geology and iron ore deposits of Serra dos Carajás, Pará, Brasil. Belém. Cia Meridional de Mineração.

VERSCHURE, R.H. e BON, E.H. - $1972-$ Geology and geocronology of tinbearing volcanoplutonic complexes in Rondônia (Western Brasil): Reflections on the genesis of this type of magmatism. A.R.Z.W.O. Lab. Isotopean Geol., Amsterdan, 1970: 177-198. 